\title{
Defoliation: its Effects upon the Growth and Structure of the Wood of Larix.
}

\author{
BY \\ ALAN G. HARPER, B.A., \\ Demonstrator in the School of Rural Economy, Oxford.
}

\begin{abstract}
With Plates XLIX and $L$ and two Figures in the Text.
\end{abstract}
\section{INTRODUCTION.}

$\mathrm{T}$

HE larch trees investigated had been defoliated for several years in succession by larvae of the large larch Sawfly (Nematus erichsoni). This pest, which since I 882 has killed nearly every larch in the Adirondacks, was suddenly reported from the English Lake District. The first mention of its presence was in September, 1906, in a memorandum of the Board of Agriculture reporting damage done by it there during that summer. It had begun its ravages there, however, as early as $1904,{ }^{1}$ and was reported from Wales and Ayrshire in 1907. Since then it has done an enormous amount of damage to larch plantations in the Lake District and in Wales, and in I9IO it was scheduled under the Destructive Insects and Pests Order of the Board of Agriculture and Fisheries. Not only the European Larch, but also the more recently introduced Japanese species (Larix leptolepis) is attacked. The nature of the damage is as follows: the larvae, emerging in early June from eggs laid a week earlier in the cortical tissues of the terminal shoots of the branches, work their way down towards the main trunk, eating every leaf as they proceed. In three or four weeks' time they drop to the ground to spin cocoons in the moss, leaving the tree completely or in part defoliated and with the terminal shoots in which the eggs were laid withered. Sometimes, however, a second flush of leaves is produced upon the spur shoots towards the end of the summer, but these are liable to injury from early frosts. The cocoons hatch out next May, and the process may be repeated year after year until the tree becomes weaker and weaker and ultimately dies for lack of nourishment. ${ }^{2}$

In so far as its green leaves are the seat of photosynthesis their untimely removal must affect the food supply of a plant. In spring, when the winter buds of trees unfold, the plastic reserves, stored up during the preceding summer, are drawn upon not only for the material of the leaf tissues itself, but also to keep up the active metabolism necessary for supplying sufficient energy or osmotic substances necessary for the actual expansion of the growing cells. That the source of this growth-energy is

1 MacDougall.

${ }^{2}$ For further details cp. the papers of MacDougall, Hewitt, and Annand.

[Annals of Botany, Vol. XXVII. No. CVIII. October, 1913.] 
the consumption of a considerable quantity of material has been shown clearly by the fact that growing trees actually lose in dry weight while their leaves are expanding from the winter buds, especially in the case of deciduous trees like the larch. ${ }^{1}$ The unfolding of the leaves, therefore, represents the expenditure of capital, and if they are lost early in the season, before an adequate interest may have accumulated, the resources of the plant are diminished. The primary physiological effect of an early defoliation is a more or less severe degree of starvation.

Accordingly, most of the facts recorded in this paper are purely starvation phenomena. Slow starvation of a growing tree is met by economy in expending the formative materials, and in the woody cylinder this may be expressed in two distinct ways: firstly, by a reduction in the amount of growth ; secondly, by a decrease in the proportion of 'mechanical tissues'; for thick-walled fibrous cells require in their formation more material than an equivalent development of thin-walled, water-conducting tracheides, and are of less immediate importance to the tree. The amount of growth is indicated by the breadth of the annual ring, and in timber so simple in structure as that of the larch, the thick-walled tissue is, generally speaking, identical with the zone of so-called autumn wood. ${ }^{2}$ Therefore both the ring-breadth and the development of autumn wood must be considered in dealing with the effects of defoliation.

The trees to be investigated were felled in October and November, I9II, after growth for that year had ceased. Complete cross-sections of the trunk were sawn out at equal distances apart, every four or five feet as the case might be. (In the tables these sections are numbered successively from the base of the tree upwards.) From each section a small rectangular block from 8 to $12 \mathrm{~mm}$. broad was cut out at the circumference opposite to each of the four points of the compass, N., S., E., and W., the north side of the tree having been marked before felling and shown by an arrow on the surface of each section as it was cut out of the trunk. From the surface of each block was cut a thin, transparent shaving for microscopic examination and measurement, and the breadth of each annual ring as a whole and of its zone of autumn wood taken separately was measured along three different radii separated tangentially by a mean distance of $2-5 \mathrm{~mm}$. Thus three sets of measurements were made for each little block, making twelve in all for each complete cross-section of the trunk, and the average of the twelve is taken as the mean radial increment for the tree at any particular height from the ground at which a cross-section may have been made.

1 Ramann and Bauer, p. 67.

${ }^{2}$ It need scarcely be remarked that this so-called ' autumn wood' is not formed in the antumn, and on the other hand the 'spring wood' is being made during the first half of the summer. There is therefore little to be gained by changing the term 'Herbstholz' into 'Sommerholz', as has been done by Hartig, and since a translation of Strasburger's still more suggestive expression 'Spätholz' is not yet generally used in this country, the terms 'spring wood' and 'autumn wood' are employed throughout this paper (cp. Hartig (1), p. I3, and (3) p. 276 ; Strasburger, p. 501 ). 
The tables I-VII show the results of some of these measurements, expressed in millimetres. Originally they were carried to two or even three places of decimals, like Schwarz's measurements for Pimus sylvestris. ${ }^{1}$ It was found, however, that the three parallel measurements of each little block varied so much among themselves, owing to the wavy character of the annual rings, that figures beyond the first place of decimals were valueless, a point which Schwarz seems to have missed through taking only a single measurement in each of the four directions of the compass, instead of three in each direction, as has been done for the purpose of these tables. ${ }^{2}$ Even in a normally grown tree like the forty-five year old larch of Table I, which had never been attacked by the Sawfly, the ' limit of error' was found to be so great as to exclude quantities smaller than one-tenth of a millimetre. This is shown by Table II, from the same tree, where the numbers are expressed as fiftieths of millimetres, reaching consequently to the second place of decimals. It has been mentioned that three parallel measurements were made in each of the four directions of the compass, making a total of twelve for each complete section of the trunk. Series I of Table II shows the greatest difference of any measurement from the mean of all the three taken in that same direction. The mean of these differences for the thirteen separate sections of the trunk and averaged over a period of six years is $0.15 \mathrm{~mm}$. for the ring-breadth and $0.16 \mathrm{~mm}$. for the autumn wood. Perhaps Series 2 of the same table gives a truer idea of the exact degree of irregularity of the rings. It shows the greatest difference between any one of the twelve measurements and the mean of them all, and the 'limit of error' so obtained and averaged, as in Series I, for the whole tree during six years is about half as much as before $-0.09 \mathrm{~mm}$. for the ring-breadth and $0.08 \mathrm{~mm}$. for the autumn wood.

TABLE I. SPECIMEN TREE A.

Height of tree, 68 feet. Sections taken every 5 feet from the base.

(a) Ring-breadth in Millimetres.

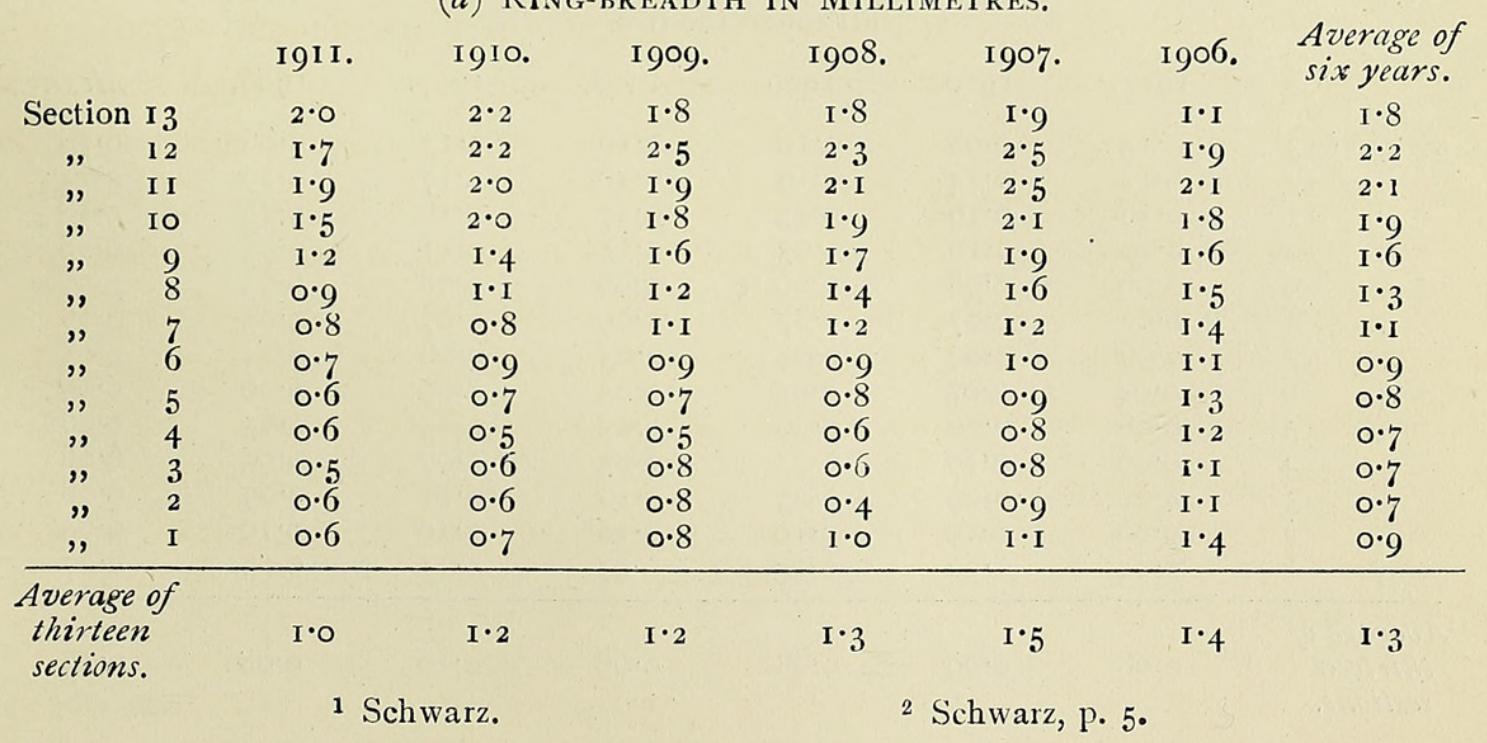


(b) Autumn Wood \%.

\begin{tabular}{|c|c|c|c|c|c|c|c|c|}
\hline \multirow{2}{*}{ Section } & & & & & I 908. & 1907. & & $\begin{array}{l}\text { Average of } \\
\text { six years. }\end{array}$ \\
\hline & I3 & 60 & 50 & $5^{\circ}$ & 60 & 30 & 40 & 50 \\
\hline ", & I 2 & 60 & $5^{\circ}$ & 50 & 50 & 60 & 50 & 50 \\
\hline 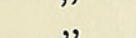 & I I & 70 & 60 & 60 & 60 & 60 & 60 & 60 \\
\hline , & I0 & 6о & 60 & $5^{\circ}$ & 50 & $5^{\circ}$ & 40 & $5^{\circ}$ \\
\hline$"$ & 9 & $5^{\circ}$ & 40 & 40 & 40 & 40 & 40 & 40 \\
\hline ", & 8 & 60 & 50 & $5^{\circ}$ & 40 & 40 & 40 & $5^{\circ}$ \\
\hline ", & 7 & 60 & $5^{\circ}$ & $5^{\circ}$ & $5^{\circ}$ & 50 & 40 & 50 \\
\hline ", & 6 & $5^{\circ}$ & 40 & 60 & 70 & 60 & 50 & 50 \\
\hline & 5 & 70 & 60 & 60 & 60 & 60 & 60 & 60 \\
\hline ", & 4 & 50 & 60 & 60 & 70 & 50 & 50 & 60 \\
\hline ", & 3 & 60 & 70 & 60 & yo & 60 & 50 & 60 \\
\hline , & 2 & 70 & yo & 60 & 70 & 60 & 50 & 60 \\
\hline ", & I & 50 & 60 & $5^{\circ}$ & 60 & $5^{\circ}$ & 50 & 60 \\
\hline $\begin{array}{l}\text { Average } \\
\text { thirteen } \\
\text { sections. }\end{array}$ & & 60 & 60 & $5^{\circ}$ & 50 & 50 & $5^{\circ}$ & 50 \\
\hline
\end{tabular}

TABLE II $a$. VARIABILITY OF RING-BREADTH, IN MILLIMETRES.

Series I. Greatest difference of any one reading from the mean of the three taken close together at that point.

\begin{tabular}{|c|c|c|c|c|c|c|c|c|}
\hline & & I9II. & I9Io. & I 909. & I908. & 1907. & I906. & Mean \\
\hline Section & 13 & 0.24 & 0.14 & $0 . I_{4}$ & 0.16 & 0.20 & ०.०6 & 0.16 \\
\hline ,, & 12 & 0.14 & 0.20 & $0 \cdot 3^{8}$ & O.I 8 & 0.40 & 0.10 & 0.23 \\
\hline " & I I & 0.46 & 0.26 & 0.30 & 0.34 & 0.22 & 0.46 & 0.34 \\
\hline ," & 10 & 0.12 & 0.24 & 0.12 & 024 & 0.26 & 0.08 & 0.18 \\
\hline " & 9 & $\mathrm{O} \cdot \mathrm{I}_{4}$ & 0.18 & 0.08 & 0.08 & 0.12 & 0.10 & $C \cdot I_{2}$ \\
\hline ," & 8 & 0.02 & 0.10 & 0.08 & O.I 6 & 0.10 & 0.06 & 0.09 \\
\hline & 7 & 0.08 & 0.06 & $c \cdot 06$ & 0.08 & 0.08 & ०.०6 & 0.07 \\
\hline , & 6 & 0.06 & 0.08 & 0.10 & 0.06 & 0.22 & 0.12 & O. I I \\
\hline " & 5 & 0.08 & 0.10 & ०.०8 & 0.06 & 0.08 & 0.08 & 0.08 \\
\hline ", & 4 & 0.12 & 0.12 & 0.06 & 0.12 & 0.12 & ०.०6 & 0.10 \\
\hline ", & 3 & 0.06 & 0.16 & 0.04 & 0.12 & 0.28 & 0.10 & 0.13 \\
\hline & 2 & 0.06 & 0.20 & 0.14 & 0.22 & $0 . I_{4}$ & 0.20 & $0.1 \%$ \\
\hline , & I & 0.10 & 0.06 & 0.08 & 0.06 & 0.18 & 0.18 & $O \cdot I_{1}$ \\
\hline
\end{tabular}

Series 2. Greatest difference of any single reading from the mean of the twelve taken all round the tree.

\begin{tabular}{|c|c|c|c|c|c|c|c|c|}
\hline & & I9II. & igro. & I909. & I908. & 1907. & I906. & $\begin{array}{l}\text { Mean. } \\
0.10\end{array}$ \\
\hline $\begin{array}{l}\text { Section } \\
\text {, }\end{array}$ & $\begin{array}{l}\text { I3 } \\
\text { I } 2\end{array}$ & $\begin{array}{l}\text { O.I } 5 \\
\text { O.I } 2\end{array}$ & $\begin{array}{l}0.08 \\
0.14\end{array}$ & $\begin{array}{l}0.10 \\
0.10\end{array}$ & $\begin{array}{l}0.10 \\
0.10\end{array}$ & $\begin{array}{l}0.13 \\
0.17\end{array}$ & $\begin{array}{l}0.06 \\
0.10\end{array}$ & $\begin{array}{l}0.10 \\
0.14\end{array}$ \\
\hline$"$ & II & 0.26 & 0.16 & 0.13 & $0 \cdot 17$ & 0.16 & 0.19 & 0.18 \\
\hline ", & IO & 0.10 & 0.10 & 0.05 & $0.1 \mathrm{I}$ & O.I I & 0.05 & 0.09 \\
\hline " & 9 & 0.06 & 0.08 & 0.06 & 0.06 & 0.08 & 0.05 & 0.07 \\
\hline ", & 8 & 0.02 & 0.07 & 0.07 & 0.09 & 0.07 & 0.05 & 0.06 \\
\hline ", & 7 & 0.06 & 0.04 & 0.04 & 0.05 & 0.06 & 0.04 & 0.05 \\
\hline , & 6 & 0.04 & 0.05 & 0.05 & 0.05 & 0.09 & 0.06 & 0.06 \\
\hline$"$ & 5 & 0.06 & 0.06 & 0.06 & 0.05 & 0.05 & 0.05 & 0.06 \\
\hline ", & 4 & 0.06 & $0 \cdot 10$ & 0.05 & 0.05 & 0.07 & 0.05 & 0.06 \\
\hline & 3 & $0.0_{4}$ & 0.09 & 0.03 & $0 \cdot 10$ & O.II & 0.09 & 0.08 \\
\hline ", & 2 & 0.06 & 0.10 & 0.10 & $0 \cdot 10$ & $0 \cdot 10$ & 0.10 & 0.09 \\
\hline ", & I & 0.04 & 0.04 & 0.05 & 0.05 & $0.1 \mathrm{I}$ & 0.13 & 0.07 \\
\hline $\begin{array}{l}\text { Avrage } \\
\text { thirteen } \\
\text { sections. }\end{array}$ & & 0.08 & 0.09 & 0.08 & 0.08 & 0.10 & 0.08 & 0.09 \\
\hline
\end{tabular}


TABLE II $b$. VARIABILITY IN BREADTH OF AUTUMN WOOD.

Series I. Greatest difference of any one reading from the mean of the three taken close together at that point.

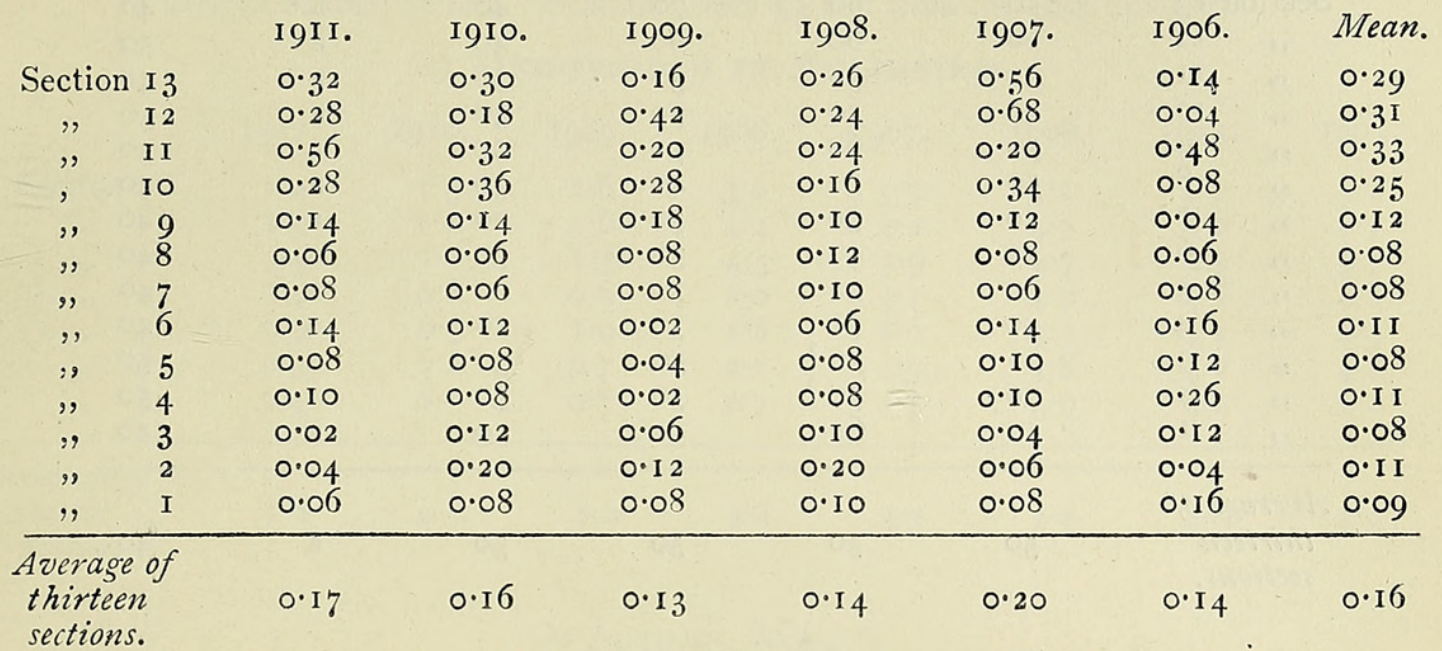

Series 2. Greatest difference of any single reading from the mean of the twelve taken all round the tree.

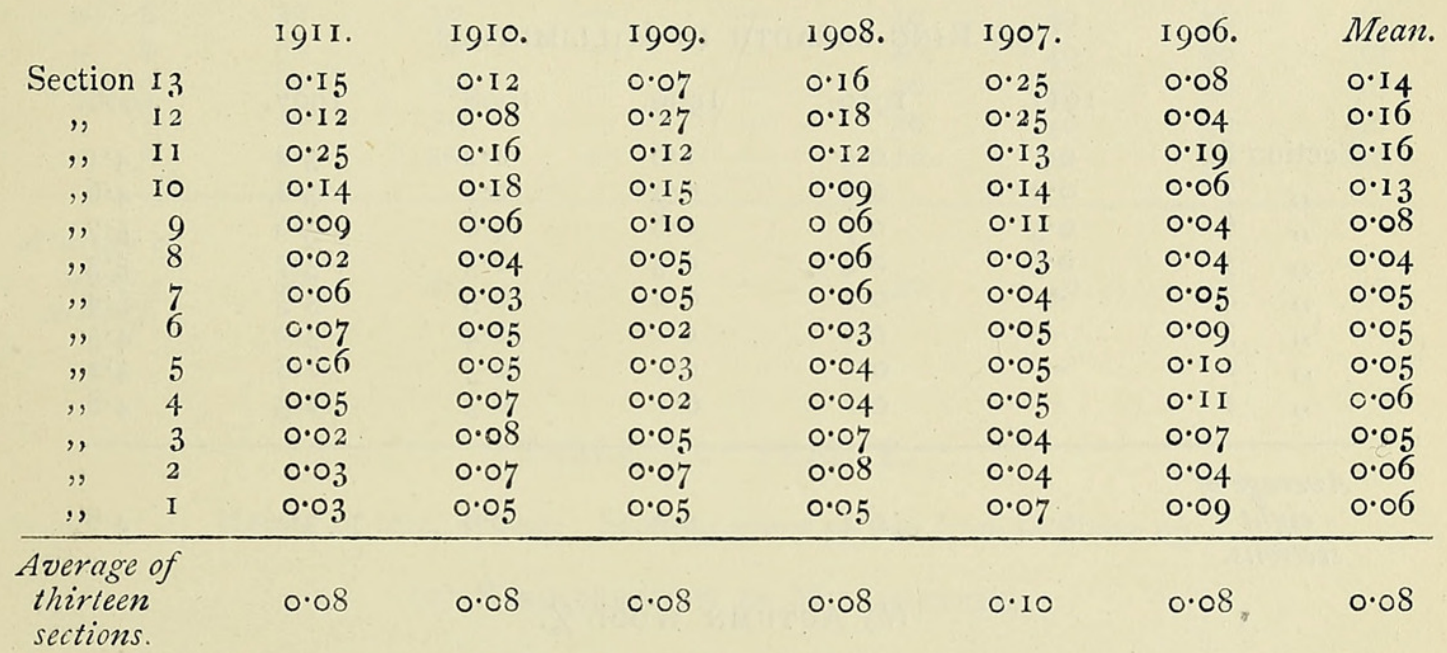

TABLE III. TREE B.

Height of tree, $6_{9}$ feet. Sections every 5 feet from the base up.

(a) Ring-BREadth in Millimetres.

\begin{tabular}{|c|c|c|c|c|c|c|c|c|}
\hline & & I9II. & 1910. & I 909. & I 908. & I907. & I 906. & $\begin{array}{l}\text { Average of } \\
\text { six years. }\end{array}$ \\
\hline Section & I 3 & $\mathrm{I} \cdot 4$ & $I \cdot I$ & 0.9 & $\mathrm{I} \cdot 4$ & I $\cdot 8$ & $I \cdot 9$ & $I \cdot 4$ \\
\hline , & I 2 & $I \cdot 9$ & $I \cdot 7$ & $\mathrm{I} \cdot 2$ & $I \cdot 2$ & $2 \cdot 2$ & $2 \cdot 3$ & $1 \cdot 8$ \\
\hline ," & I I & I. 5 & $I \cdot 4$ & $I \cdot I$ & 0.9 & $2 \cdot 3$ & $2 \cdot 4$ & $1 \cdot 6$ \\
\hline ", & 10 & $I \cdot 6$ & $\mathrm{I} \cdot 5$ & $I \cdot 2$ & 0.9 & $2 \cdot I$ & $I \cdot 8$ & $I \cdot 5$ \\
\hline , & 9 & $I \cdot 4$ & $I \cdot O$ & 0.6 & 0.6 & $I \cdot 8$ & $I \cdot 2$ & 0.9 \\
\hline , & 8 & 0.8 & 0.6 & 0.5 & 0.6 & $1 \cdot 7$ & I. 4 & 0.9 \\
\hline " & 7 & 0.6 & 0.4 & 0.4 & 0.5 & $I \cdot 4$ & $I \cdot \dot{6}$ & 0.8 \\
\hline , & 6 & 0.4 & 0.3 & 0.3 & 0.4 & $I \cdot 5$ & $I \cdot 5$ & 0.7 \\
\hline ", & 5 & 0.4 & 0.4 & 0.3 & 0.5 & $\mathrm{I} \cdot 5$ & $1 \cdot 7$ & $0 . \dot{8}$ \\
\hline " & 4 & 0.5 & 0.2 & 0.3 & 0.4 & $I \cdot 6$ & $\mathrm{I} \cdot 8$ & 0.8 \\
\hline ," & 3 & 0.4 & 0.1 & 0.2 & 0.3 & $I \cdot 6$ & $\mathrm{I} \cdot 8$ & 0.7 \\
\hline , , & 2 & 0.3 & $0 \cdot I$ & 0.2 & 0.3 & I. 4 & $I \cdot 7$ & 0.7 \\
\hline ", & I & 0.6 & 0.5 & 0.2 & 0.4 & $I \cdot 4$ & $2 \cdot I$ & 0.9 \\
\hline $\begin{array}{l}\text { Average } \\
\text { thirteen } \\
\text { sections. }\end{array}$ & & 0.9 & 0.7 & 0.6 & 0.6 & $I \cdot 7$ & I $\cdot 8$ & $I \cdot O$ \\
\hline
\end{tabular}


(b) Autumn Wood \%.

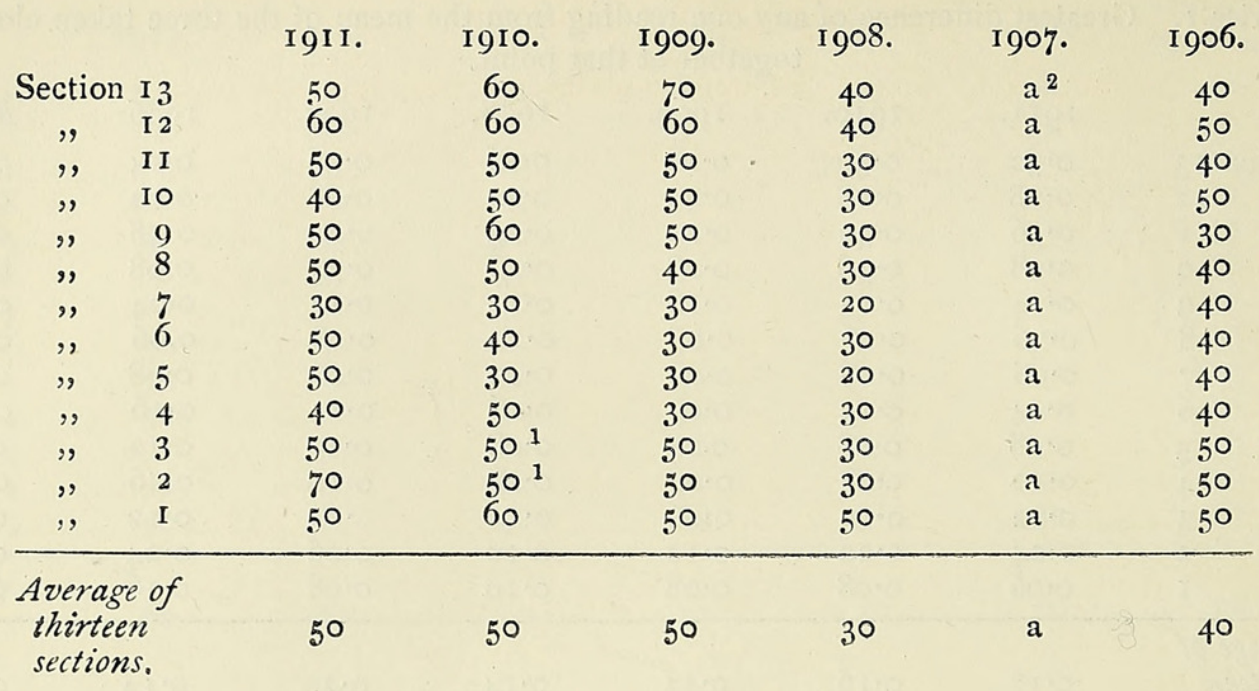

TABLE IV. TREE C.

Height of tree, 35 feet. Sections every 4 feet from the base up.

(a) Ring-Breadth in Millimetres.

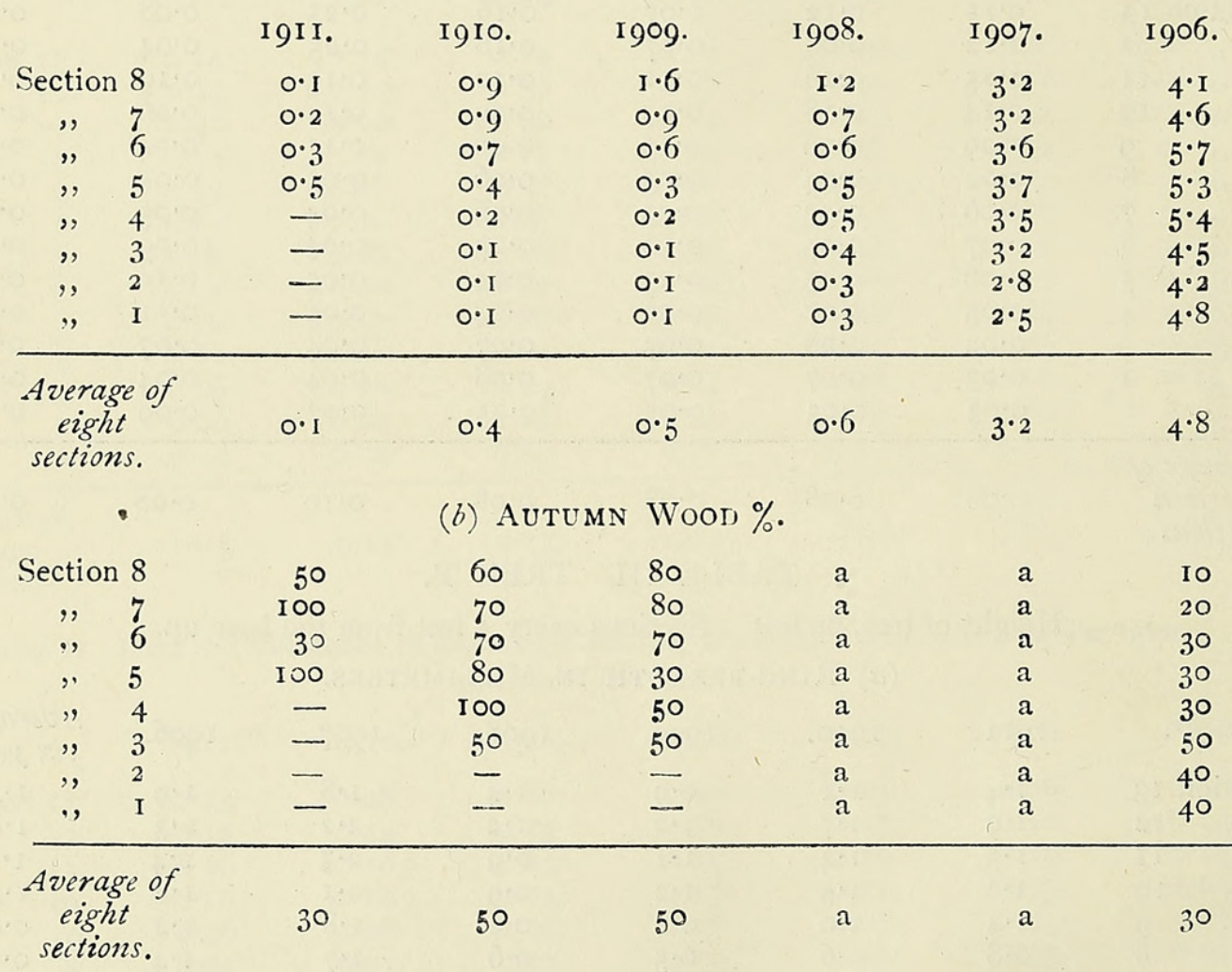

1 As these measurements are approximated to the first place of decimals (p. 623), the autumn wood is not expressed at all when it is less than $0.05 \mathrm{~mm}$. in breadth. When more than $0.05 \mathrm{~mm}$. broad the autumn wood would be expressed as $0.1 \mathrm{~mm}$., so that when the whole ring-breadth sinks to $0.1 \mathrm{~mm}$. (as in the cases marked thus ${ }^{1}$ ) these tables can no longer express the percentage of autumn wood. An assumption of 50 per cent. has been made in such cases, and the error so caused is a slight one when averaged for the whole tree.

2 The letter ' $a$ ' is used in these tables to signify that the autumn wood is abnormal in that its cell-walls are not properly thickened, at least towards the boundary of the ring. In such cases measurements would be misleading. 
TABLE V. TREE D.

Height of tree, $3^{8}$ feet. Sections every $5_{2}^{\frac{1}{2}}$ feet from the base upwards.

(a) Ring-Breadth in Millimetres.

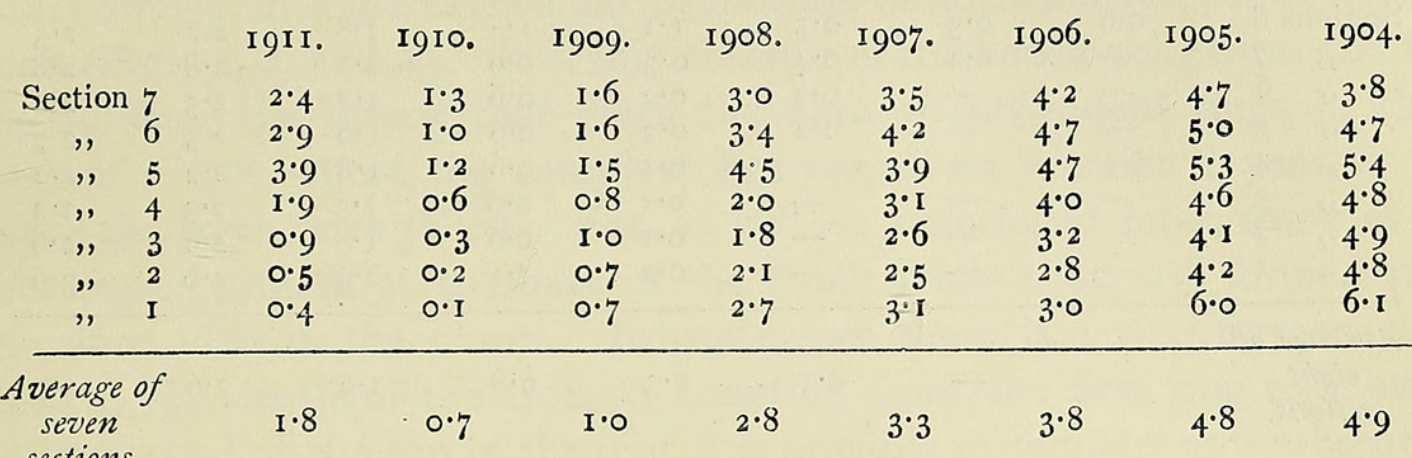

sections.

(b) Autumn Wood \%.

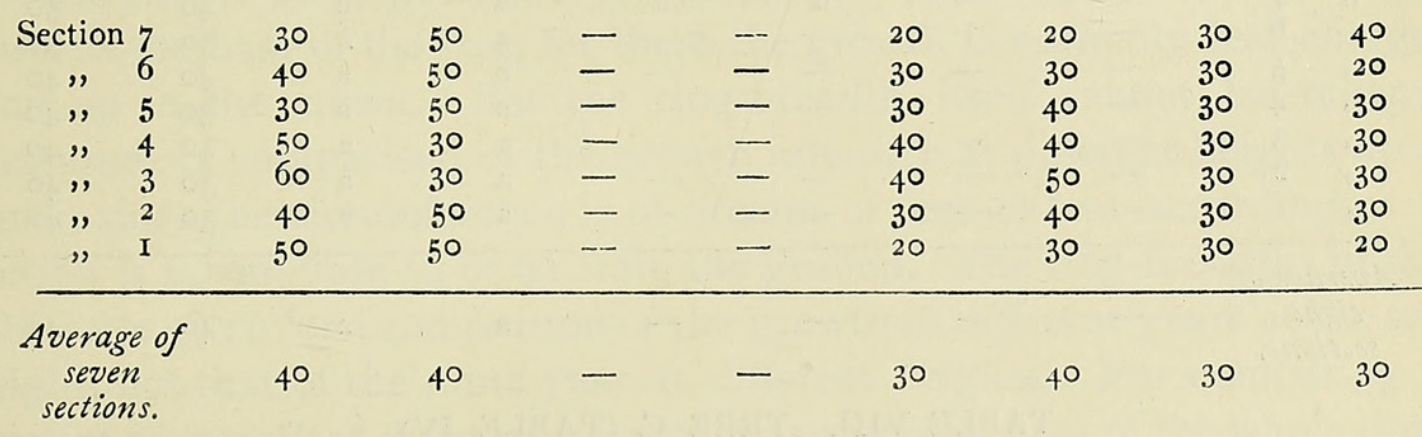

TABLE VI. TREE E.

Height of tree, 37 feet. Sections every $5 \frac{1}{2}$ feet from the base up.

(a) Ring-Breadthi in Millimetres.

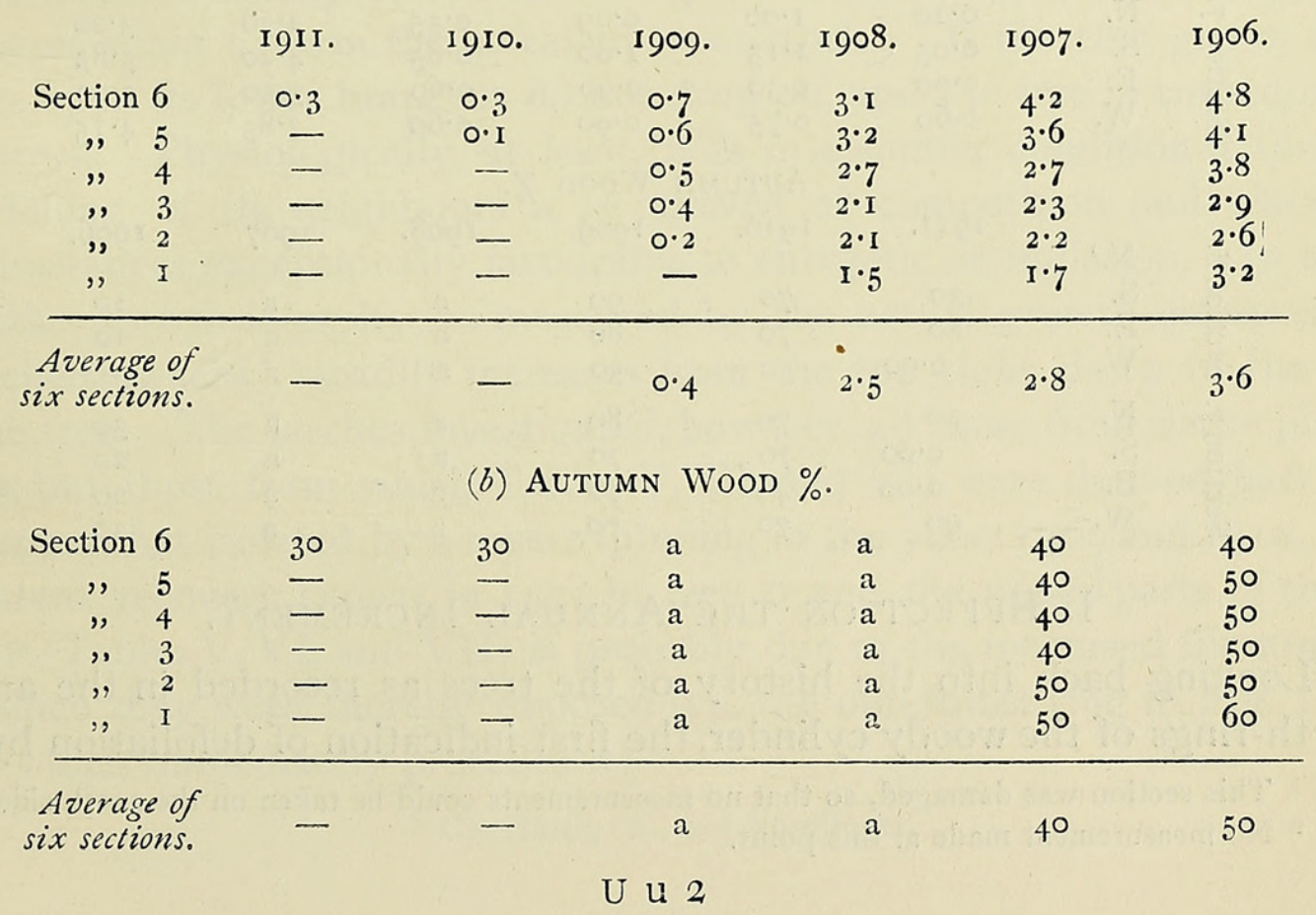


TABLE VII. TREE F.

Height of tree, 45 feet. Sections every $5 \frac{1}{2}$ feet from the base up.

(a) Ring-BReadth in Millimetres.

\begin{tabular}{|c|c|c|c|c|c|c|c|c|}
\hline & I9II. & I9ro. & 1909. & I908. & 1907. & 1906. & 1905. & $\begin{array}{r}1904 . \\
2.5\end{array}$ \\
\hline $\begin{array}{c}\text { Sections } 8 \\
7\end{array}$ & 0.6 & 0.3 & 0.5 & $\begin{array}{l}\mathrm{I} \cdot \mathrm{I} \\
0 \cdot 5\end{array}$ & $\begin{array}{l}\mathrm{I} \cdot 4 \\
0.0\end{array}$ & $\mathrm{I} \cdot 8$ & $\begin{array}{l}2.2 \\
2 \cdot 8\end{array}$ & $2 \cdot 5$ \\
\hline $\begin{array}{ll}\# & 7\end{array}$ & E & 0.2 & $\begin{array}{l}0.4 \\
0.2\end{array}$ & $\begin{array}{l}0.5 \\
0.2\end{array}$ & $\begin{array}{l}0.9 \\
0.6\end{array}$ & $\begin{array}{l}2 \cdot \mathrm{I} \\
\mathrm{I} \cdot \mathrm{7}\end{array}$ & $\begin{array}{l}2 \cdot 8 \\
2 \cdot 5\end{array}$ & $2^{\circ}$ \\
\hline$" \quad 5$ & - & - & 0.2 & 0.2 & 0.6 & $1 \cdot 6$ & 2.5 & \\
\hline , & - & - & - & O. I & 0.6 & $I \cdot 8$ & $2 \cdot 2$ & \\
\hline ", & - & - & - & $0 \cdot \mathrm{I}$ & 0.6 & I. 5 & $2 \cdot 3$ & $2 \cdot 2$ \\
\hline ," & - & - & - & $0 . \mathrm{I}$ & 0.6 & $\mathrm{I} \cdot 8$ & $2 \cdot \%$ & \\
\hline 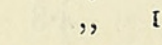 & - & - & - & 0.2 & $I \cdot I$ & $2 \cdot 9$ & 4.0 & . \\
\hline $\begin{array}{c}\text { Average } \\
\text { eight } \\
\text { sections. }\end{array}$ & - & - & $0 . \mathrm{I}$ & 0.3 & 0.8 & $\mathrm{I} \cdot 9$ & $2 \cdot 6$ & \\
\hline
\end{tabular}

(b) Autumn Woop \%.

\begin{tabular}{|c|c|c|c|c|c|c|c|c|c|}
\hline Section & 8 & 70 & 30 & a & $\mathrm{a}$ & a & a & 60 & 50 \\
\hline " & 7 & - & - & $\mathrm{a}$ & a & a & $a$ & 40 & $5^{\circ}$ \\
\hline , & 6 & - & - & - & - & a & a & 30 & 30 \\
\hline , & 5 & - & - & - & - & a & a & 40 & $4^{\circ}$ \\
\hline , & 4 & - & - & - & - & a & a & 30 & $4^{\circ}$ \\
\hline ", & 3 & - & - & - & - & a & a & $4^{\circ}$ & $4^{\circ}$ \\
\hline ," & 2 & - & - & - & - & a & a & 30 & 40 \\
\hline$"$ & I & - & - & - & - & $a$ & a & 30 & $4^{\circ}$ \\
\hline $\begin{array}{l}\text { Averas } \\
\text { eight } \\
\text { section }\end{array}$ & $\begin{array}{l}\text { oe of } \\
\text { ths. }\end{array}$ & - & - & - & - & $a$ & $a$ & 40 & 40 \\
\hline
\end{tabular}

TABLE VIII. TREE C (TABLE IV).

RING-BREADTH (given to the nearest $0.0_{5} \mathrm{~mm}$.).

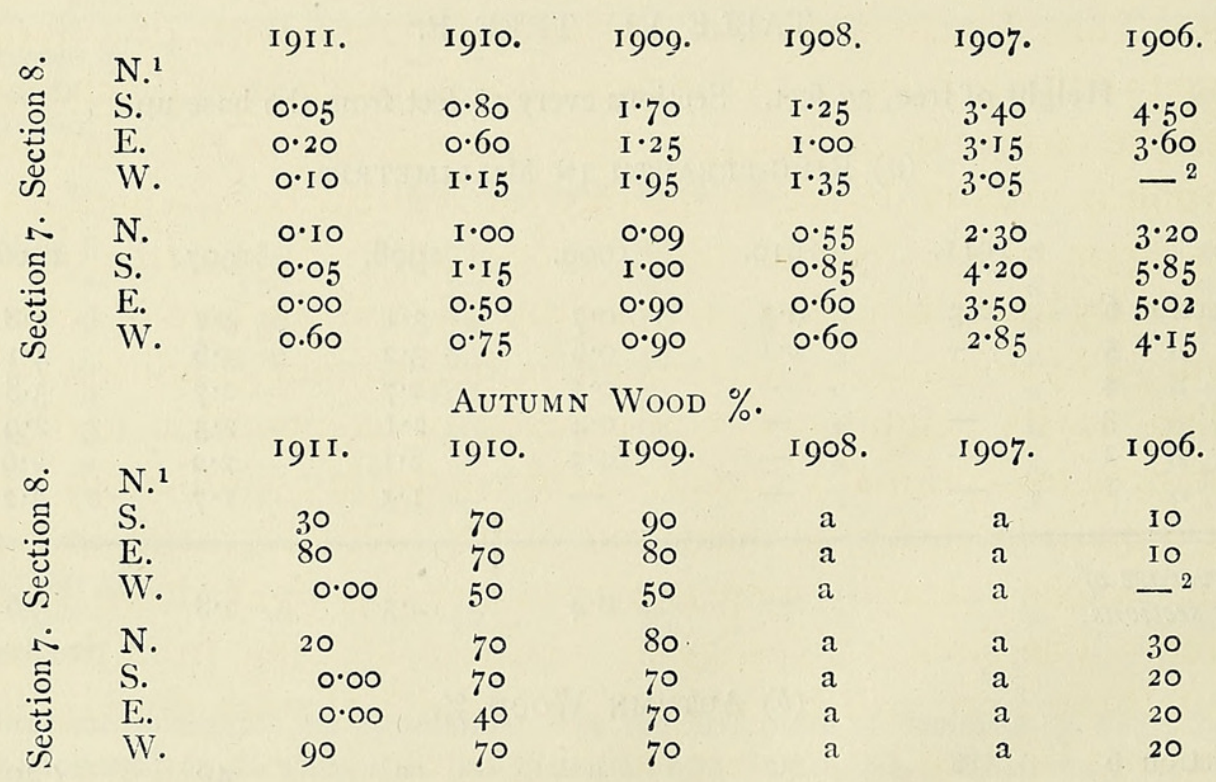

\section{EFfeCt on the AnNuAl InCREment.}

Looking back into the history of the trees as recorded in the annual growth-rings of the woody cylinder, the first indication of defoliation by the

1 This section was damaged, so that no measurements could be taken on the north side.

2 No measurement made at this point. 
Sawfly larvae is the striking absence of the strongly thickened tracheides that usually occur as the zone of 'autumn wood' at the close of the year's growth (P1. XLIX, Figs. I, 2, and 3). At first, perhaps, there is no significant decrease in the ring-breadth itself, but subsequent years show much narrower rings, with, however, in some cases a fair proportion of normally thickened autumn wood (Figs. I, 2, and 4). It is this absence of thickened cells from the first ring to show the attack that gives the date of subsequent rings in those parts of a tree where the cambium has ceased to function a year or two before the trees were felled. For, as will be mentioned later, some of the trees ceased growth at the base of the trunk while they still formed rings year after year in the crown. In the crown there is a ring formed every year till the death of the tree, so, counting from the first ring to show no autumn wood at the top of the tree, it is possible to compare any subsequent ring with the corresponding growth for the same period lower down the trunk.

As might be expected, these starvation effects are most in evidence towards the base of the tree, for there the growth is normally less energetic than up in the crown. But the ring-breadth itself cannot be taken as a measure of comparison of the growth intensity at different heights up the trunk, since the circumference is of greater or less extent according as the section is taken close to or far from the ground. The ring-breadths in these tables are given for a comparison of the growth in different years at the same height, not that of the same year at different heights. For comparing the amount of growth at different heights the superficial area of the whole ring in cross-section of the trunk would be required, the 'Flächenzuwachs' of German foresters. This 'Flächenzuwachs' varies in different parts of a normal tree according to definite rules. ${ }^{1}$ In the crown, for instance, the 'Flächenzuwachs' increases the farther down one gets from the top, but in the branchless part of the trunk it usually decreases steadily towards the base, where it suddenly increases again to form the so-called 'root-stock'. If the tree grows alone in the open its lower branches do not drop off, and the tree is consequently all crown. Physiologically, at least, it is in a similar condition if through the felling of its neighbours it is relieved of competition and placed in circumstances exceptionally favourable to energetic assimilation. In either case the growth-intensity, as measured by the actual growth-increment or 'Flächenzuwachs', steadily increases from the top right down to the base of the tree. The larches investigated, however, all came from dense plantations, but those from which Tables V, VI, and VII were derived had been left somewhat isolated by a severe thinning in the years I 909 and I9IO. The apparent recovery shown in IgII in tree $\mathrm{D}$ and the upper parts of trees $\mathrm{E}$ and $\mathrm{F}$ (Tables V, VI, and VII) is probably due to the increased illumination to which they were thereby exposed (cp. the outermost ring in Fig. I with that which immediately precedes it).

\footnotetext{
1 Cp. Hartig (2), and Nördlinger.
} 
Owing to the denseness of the plantations the crowns of these larches would be restricted in development, and down the bare trunk below the lowest of the branches the growth-intensity, and with it the 'Flächenzuwachs', would steadily decrease towards the base of the tree. Now if as one gets nearer and nearer to the base the whole sectional area of the annual ring is becoming less, while at the same time the circumference is steadily increasing as the thicker parts of the trunk are reached, it is clear that the breadth of the ring must decrease in a very striking manner, as is shown by Table I for a larch that had never been attacked by the Sawfly, and which may therefore be taken as a standard of comparison for the others. In the column showing the average ring-breadth for the last six years there is a regular gradient from section to section except at two points only. One of these is at the very base of the tree (section I), at the root-stock in fact, where, as has been said, exceptional growth is to be expected. The other is in the topmost section, from the uppermost part of the crown, where the annual increment falls off again very rapidly according to the rules already mentioned.

The reasons why growth varies in different parts of the tree cannot be dealt with at length in this paper. Various explanations have been put forward. Schwarz ${ }^{1}$ would refer the matter to differences in the longitudinal pressures acting on the cambium, these varying inversely with the strength of the wind's leverage at any part of the trunk and the capacity of resisting this bending force. Hartig ${ }^{2}$ seeks a sufficient cause in supposed differences in the distribution of carbonaceous food-materials, mineral salts, of soil and air temperatures, \&c. The facts themselves are enough for the present, and indeed a single satisfactory explanation of them has not yet been suggested.

These facts of distribution and localization of growth-intensity in normal trees have an important bearing on cases where the vitality has been lowered through defoliation or other causes. For when growth is reduced it will naturally cease first where it is normally least. In stunted trees, for instance, rings which fail close to the base may reappear in the root-stock, the growth there being normally greater than immediately above it. $^{3}$ The narrower rings, therefore, may be altogether absent from the base of the tree, though at the top it is still possible to count back ring by ring to the year of the commencement of the attack or depression of growth (see Tables IV, VI, and VII). Or at the base, again, a ring that is feebly developed may only reach part of the way round the tree (Fig. 6), though it may be complete higher up. 'Partial rings,' in fact, may arise over very small arcs of the circumference, only small circumscribed patches of the cambium mantle being active (A in Fig. 7). These partial rings are quite distinct from the 'multiple rings' that are occasionally found in larch and other trees, where at first sight several rings appear to have been
1 Schwarz, pp. 2 and 160.
2 Hartig (3), p. 27 I.
3 Cp. Schwarz, p. 2 I 3. 
formed in one year. For though in a multiple ring the successive bands of autumn wood often run together in places (as in Pl. L, Fig. I3), and so unite to form a single ring round the rest of the circle, in a partial ring the circuit is completely interrupted for a greater or lesser extent. Now even in undefoliated trees rings may be partially or wholly absent from the base of the trunk if growth becomes stunted through overshading or unsuitable soil. ${ }^{1}$ When therefore a similar result is observed to follow on defoliation it can only be referred to the same cause-lowered vitality brought about by starvation.

A priori it might be objected that annual differences of temperature or rainfall might minimize the value of comparisons between the growths of successive years. Table I, however, for a tree that had never been attacked, shows that the influence of such climatic variations has been quite insignificant during the last six years. Of the other examples for which measurements are given two more came from this same area in Central Wales, while three are from the neighbourhood of Thirlmere. And since all the trees examined were of much the same age (from thirty to forty-five years) and were all planted at much the same altitude (500 to 650 feet), there remain no good reasons for supposing that the defoliations have not been the chief or even the sole factor in causing the reduction both of the breadth of the whole ring and the proportion of autumn wood.

Of course the effects of defoliation vary in intensity according both to the severity of the attack and to the vigour of the tree at the time. Despite repeated defoliations the trees $\mathrm{B}, \mathrm{C}$, and $\mathrm{D}$ were reported to be still flourishing when they were felled, and only in one of these, C, were rings at all absent, and then only in the lower parts. Table VI, on the other hand, represents a tree that was dead at the time of felling, like two others for which measurements are not given, and in all three of these dead trees growth had ceased entirely at the base one or more years before they were felled, though the upper parts still formed a ring each year. Between the upper parts, where the cambium still remained active, and the lower parts, where it had become quiescent, the partial rings already described were of frequent occurrence. The tree F (Table VII) was said by a competent authority ${ }^{2}$ to be dying when it was felled, and certainly it shows at its base the same absence of rings as the three dead trees just mentioned. It would seem from these examples that where vitality has reached so low an ebb that growth quite ceases at the base, the tree is not likely to be able to withstand another defoliation, even though it is still growing at the top, as in Table VII. But as long as it is still growing at the base it would seem to have sufficient reserve food-materials left to enable it to put forth further crops of leaves season by season until it may ultimately outlive the present infestation by the Sawfly. Nevertheless, in all the cases investigated the attack has 
seriously interfered with the growth-increment upon which the forester naturally bases his expectation of financial returns.

\section{EFFects on the Structure of the WoOd.}

The effects of defoliation upon the amount of growth and the consequent breadth of the annual growth-ring having now been described, there remain to be considered some modifications which have been brought about in the structure of the timber. Essentially these changes consist in a decrease in the ratio which the thick-walled 'mechanical' elements bear to the porous water-conducting tissue, and since in a tree like the larch the spring wood consists entirely of thin-walled tracheides, while the thickwalled cells are massed together towards the outside of the ring as the zone of autumn wood, it is in this outer region that the histological effects of defoliation become apparent. There are two distinct ways in which the autumn wood may be affected. Firstly, its breadth relatively to the breadth of the whole ring may decrease, but without any accompanying diminution in the characteristic thickening of the cell-walls. Secondly, this normal thickening may be poorly developed or even wholly lacking for part, especially the outer part, or even the whole of the breadth of the autumn zone, so that it is only from the smaller size of its outer cells and their flattened shape at the very limit that the ring can be demarked from the one that succeeds it (Fig. 3), and in extreme cases the boundary is no longer to be traced with any accuracy (Fig. 9, between A and B).

Now the autumn wood of the first year to show evidence of the attack of the Sawfly is never normal; it is affected in the second of the two ways just mentioned, being deficient in the thickening of its cell-walls. In subsequent years, however, in spite of continued repetition of the defoliations, it may consist once more of normally thickened tracheides, in narrow zones commensurate with the decreased breadth of the whole ring (cp. Figs. I, 2, 4, 6, 9, and Tables III, V, VII). But such a return to normally thickened autumn wood never occurred in such trees as ultimately succumbed before they were felled for the purposes of this investigation. Fig. 8 shows a typical example of the appearance of the last-formed ring of one of these, and may be contrasted with Fig. 4, taken from the tree C, which was still vigorous at the time. On the other hand, examples $\mathrm{D}$ and $\mathrm{F}$ formed in the last two years before felling even an increasing percentage of quite normally thickened autumn wood (Fig. I). They were said to have been only partially defoliated in those two years, but the betterment seen in the development of their autumn wood is probably referable rather to the fact already mentioned, that the plantations from which they came were thinned at that time; for even tree $\mathrm{E}$, from the same plantations, made at the top an increased proportion of autumn wood, though not properly thickened, in the very year in which it succumbed (Table VI). 
(a) Breadth of Zone of Autumn Wood.

But the importance that might otherwise be attached to the breadth of the zone of autumn wood is perhaps increased by the consideration of the uppermost section of tree C. This section was taken seven feet below the tip of a well-grown tree with an exceptionally well-developed crown that extended, in fact, more than half-way towards the ground. Fig. I I shows the east side of the section, where the outermost ring is composed almost entirely of autumn wood; Fig. I2, from the west side of the same section, shows the same ring consisting of nothing but spring wood; while on the south side of the section the ring disappears altogether (Text-fig. I). Only four feet lower down (Text-fig. 2) it is the west side that shows the more striking development of autumn wood for this particular year, and the east side has about the normal proportion (about $5 \circ$ per cent.), while the ring is very narrow and of unthickened tracheides on the north side and practically disappears again on the south.

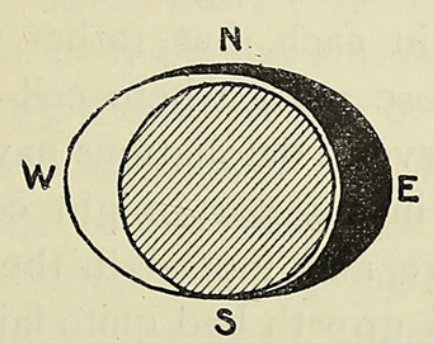

TeXT-Fig. I.

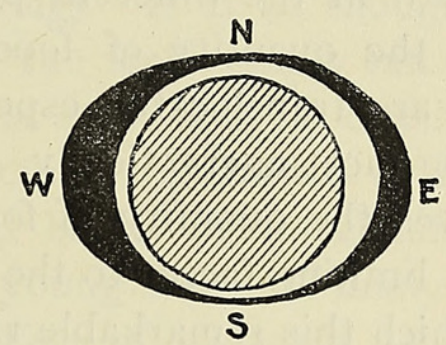

TEXT-FIG. 2.

Diagrammatic representations of the last year's growth of the two uppermost sections of the same tree, the autumn wood being shaded (cp. Table VIII).

The correct interpretation of these two sections requires some adequate understanding of the physiological causes of autumn wood formation. Clearly the difference between the east and west sides of the uppermost section could not be explained on Sachs's ${ }^{1}$ hypothesis that the characteristics of autumn wood tracheides are due to constriction of the cambial region by the encircling bark; moreover, Krabbe ${ }^{2}$ has proved that this supposed periodically recurrent compression of the expanding cells does not exist. Schwarz ${ }^{3}$ refers the formation of thick-walled tracheides to the stimulus of longitudinal stress during bending by the wind. Wieler ${ }^{4}$ and Hartig ${ }^{5}$ suppose it to be largely a question of nutrition, but whereas the former concludes that autumn wood is produced because conditions of growth are becoming less favourable, the latter considers that thick-walled cells are due to the extra nutriment that has been accumulating during the summer. Strasburger ${ }^{6}$ and Haberlandt, ${ }^{7}$ on the other hand, considering the function

1 Sachs (1), p. 409.

4 Wieler, p. I 29.

7 Haberlandt, p. 37 I.
2 Krabbe, p. I 125.

5 Hartig (1), pp. 34 and 103.
3 Schwarz, p. 365.

6 Strasburger, p. 949. 
of the thin-walled spring wood, suppose that its formation is regulated by the requirements of the transpiring crown; when these needs are adequately provided for only thick-walled autumn wood cells are formed until growth ceases for the year. Pfeffer ${ }^{1}$ cautiously admits that nothing definite is known of the causes of the seasonal change in structure of the woody ring.

In the particular case of the uppermost of these two sections it is especially noteworthy that the ring fails altogether on the south side instead of being intermediate in condition between the east and west, as it should have been if differences of temperature or wind-pressure had been the cause of the inequality shown by Figs. I I and I2. It is hard to suppose that the transpiration of the symmetrically developed uppermost few feet of the crown above the section should have been so negligible on the east side if it were responsible for all the spring wood on the west; but there might have been a difference in the nutrition of the opposite sides of the section at that point. Now the distribution of growth in a thriving and well-nourished tree lends weight to the view taken by Sachs ${ }^{2}$ and $\mathrm{Pfeffer}^{3}$ that growth in the different parts of a plant is not governed in the first place by the quantity of food available in each, but rather that foodmaterials are translocated especially to those parts where cell-division is proceeding most energetically. But after several defoliations have reduced the reserves the quantity of food at hand in any part might conceivably become a limiting factor to the growth there, and, indeed, in the particular tree in which this remarkable ring occurred growth had quite failed at the base a year or two before, which suggests that the upper parts even might have become by this time very sensitive to slight local variations in food supply. Numerous 'ringing' experiments seem to show that the elaborated food-materials tend to pass vertically down the trunk without diffusing around in all directions, so that in a very impoverished tree growth of the main stem might be taking place only just below the point of junction of each branch. ${ }^{4}$ Supposing in such a case that just above the section there were a branch on the east side, but that on the west the nearest considerable branch were a little higher up, it is easy to see that the east side of the section would get the more food, while on the west the descending nutriment, having farther to go, might not last out so far down as the point where the section was taken. A similar result would follow if the west side of the crown were more severely defoliated than the east.

It is unlikely that the formation of autumn wood in general can be the result of a single cause, but in this particular case differences in the amount of food-material available on either side of the section seem to afford the explanation most fitting to the facts described. This matter cannot be settled until the whole of the upper part of a starving tree has been

1 Pfeffer (1), p. 215.

${ }^{2}$ Sachs (2), p. 439 .

${ }^{4}$ Cp. Nördlinger, p. 3 ; Hartig (2), p. 23. 
sectioned at every few inches, the position of the principal branches being carefully noted at the same time. Such a method was precluded from the present investigation because sections had only been obtained at every fourth foot. On a future occasion I hope to throw some light on this interesting matter.

\section{(b) Anomalous Formation of Autumn Wood.}

In certain rings the defoliations have produced a striking anomaly in the autumn wood formation, traceable in every section from the top of the tree to the bottom. Such rings are denoted in the tables by the letter ' $a$ ', and show as it were a tentative formation of autumn wood. There is first a zone of the rounded thickened cells that ordinarily occur in Coniferous timber as a transition between the thin-walled spring tracheides and the tangentially flattened, thick-walled 'Grenztracheiden' ' that limit a normal annual ring, but then, instead of the typical 'Grenztracheiden', these abnormal rings pass on to a renewed production of thin-walled cells to form their outer limit (Fig. 4, innermost ring). It is as though the tree had begun to make its autumn wood but the food supply ran short, and consequently the thickening of the cell-walls could not be continued right up to the boundary of the ring. The actual appearance of this thickwalled zone recalls somewhat the isolated bands of 'mechanical' tissue commonly found in the spring wood of the young shoots of many Conifers. ${ }^{2}$ These bands have been referred to the effect of supposed alterations of pressures acting upon the cambium, and Schwarz, ${ }^{3}$ as has been said, goes even so far as to regard the longitudinal stresses occasioned by bending as the main stimulus to the thickening of the cell-walls of normal autumn wood. If this view is correct, it is possible to account for the want of thickening in the walls of the outermost cells of these abnormal rings on the theory that after defoliation the wind could not sway the tree so much as before, and consequently the bending forces would be less.

Besides these two suggestions, viz. that the increased proportion of autumn wood is due to lack of food, or to reduced pressure, or perhaps to a combination of both, there is a third possible factor to be considered. It has been mentioned that Strasburger, with Haberlandt and others, held that spring wood was formed just so long as the shooting of the young leaves required fresh provision of water-conducting tissue. According to this view a second flush of leaves would mean a renewed formation of spring wood, and the reason why 'Lammas' shoots do not always cause a 'double ring' is that the second crop of leaves may burst out before autumn wood formation has begun. Strasburger ${ }^{4}$ mentions the case of a twenty-year-old larch which once at least had formed a double ring after

\footnotetext{
1 Cp. Hartig (1), Fig. 3, p. 12.

3 Schwarz, pp. 2 and 160.
}

2 Cp. Sanio, p. I0I.
4 Strasburger, p. 949 . 
a second leafing due to an especially favourable autumn. But in this same tree a second crop of leaves did not always mean a double ring, especially in the lower parts of the trunk, for there autumn wood formation generally begins a little later than in the upper parts. Now after defoliation by the Sawfly larvae the larches sometimes put out fresh leaves towards the close of the summer, possibly after the formation of autumn wood has already begun. Spring wood is generally formed between the middle of April, when growth begins, and the end of June, after which month autumn wood is produced, until growth ceases about the end of August or beginning of September. ${ }^{1}$ The defoliation of the larches, beginning in June, is usually over by the end of July, and a second crop of leaves may appear about the middle of August, i. e. before the end of the year's growth. According to Strasburger's view, these new leaves would stimulate the cambium to a renewed formation of spring wood outside the first few autumn tracheides, while the lateness of the season or scarcity of food might preclude a second development of autumn wood to finish off the ring.

Another explanation of the abnormal formation of thin-walled cells at the outer limit of a ring may be put forward on the grounds of experiments by Lutz, who found that artificial defoliation and prevention of a second leafing led to the production of spring wood at a time of year when autumn wood was to be expected. ${ }^{2}$ He supposes that the decreased transpiration of the defoliated branches had resulted in the tree filling with water, and that the presence of much water determines the formation of spring wood. This view, in opposition to that held by Strasburger and by Haberlandt, already mentioned, is supported by the fact that on wet ground Pimus sylvestris makes very poor autumn wood, ${ }^{3}$ and it would seem to be applicable to those defoliated larches where a second leafing has not occurred or is only partial.

To determine, if possible, how far altered conditions of nutrition or a second growth of leaves might affect the formation of autumn wood, certain larches were investigated in districts free from the Sawfly, but where the abnormal summer of I9I I had destroyed some of the shoots of that year, thus prematurely cutting short the normal elaboration of food materials. For instance, in some young Japanese Larches growing near Oxford, all the shoots of I9I I had been dried up at the tips, so that all the leaves of the following summer were of necessity those of spur shoots. When one of these trees was examined it was found that in the ring of I9I I the zone of thick-walled autumn wood passed quite suddenly into a very narrow zone of thin-walled cells quite distinct from the spring wood of I 9 I 2 by reason of smaller size and tangential flattening. This linthickened zone was found throughout the whole tree; its cells seemed to have been

1 Cp. Hartig (1).
${ }^{2}$ Lutz, 1895. I am at present investigating this matter. ${ }^{3}$ Cp. Ramann and Bauer. 
somewhat crushed by the next year's growth, and their general appearance was of cells just cut off from the cambium, and which consequently had not yet lost their prismatic form or gained a thicker cell-wall. A few yards off from this tree was another Japanese Larch of the same age, but which showed no external traces of injury from the drought of I9II. It showed, however, outside the normal autumn wood for that year, a thin-walled zone of flattened cells similar to that just described in the other tree, but with rather thicker walls and not at all crushed.

It seems, then, that in both these trees there had been a check to the autumn wood formation, followed by renewed growth. In the case of the first tree, which had lost the help of its terminal shoots, there was perhaps not enough food-material for a proper thickening of the cells then formed. But in the second example the shoots were all still able to function, and so the cells could be better thickened and might have been almost normal if the approach of the winter had not checked their further development.

Investigations were also made in Kent upon a twenty-year-old larch tree which in September, I9I 2, was bearing a second flush of leaves on some of its spur shoots while other parts of the tree were still dark green, having retained the needles put forth in the spring. This second flush was especially noticeable on the spur shoots of the branches whose terminal bud had been killed in the preceding year. In none of the branches investigated, whether bearing a second flush or not, was there anything abnormal in the ring of I9I2. But as the formation of autumn wood had set in before this second flush of leaves was fully grown, there should have been already induced by them some beginnings of a second thin-walled zone if such, as Strasburger suggested, were the natural consequence of a second leafing. Traces of such a zone, however, were found in the ring of IgII, both in branches whose terminations had been injured that same year and also in those which were continued on unharmed into the shoot of IgI 2. The inference is that a zone of thin-walled cells outside the autumn wood is not caused by a second flush of leaves, but rather by inferior nutrition consequent upon unfavourable conditions of growth, such as were of common occurrence during the drought of I9II. The Japanese Larches from Oxford support the same general conclusion.

It must be admitted that the extreme youth of the only branches of this Kentish tree that were in fit condition for such comparisons detracts somewhat from the value of the conclusions obtained from them, and a similar reason lessens the importance of the two seven-year-old Japanese Larches. For in young trees and branches the formation of autumn wood frequently tends to be abnormal and deficient in thickening of its cell-walls, ${ }^{1}$ or marked by the bands of mechanical tissue already referred to, the so-called 'Druckzonen' ${ }^{2}$ which may appear in the spring wood. But

\footnotetext{
$1 \mathrm{Cp}$. foot-note on next page.
}

2 Cp. Schwarz, p. 237. 
so constant a difference as was found between the thick-walled autumn wood of the Japanese Larches and the abnormal thin-walled zone outside it is not easily explained merely by the youth of the trees. Whatever inferences can be drawn from these cases are all in favour of the view that diminished nutrition may be a cause of the occurrence of unthickened cells at the boundary of the autumn wood.

For the view that in the autumn wood of the defoliated larches such an abnormal formation of thin-walled cells outside the thickened ones is really a starved attempt at autumn wood, there is yet a further argument in the steadily decreasing size of the cells from the beginning of the thickened zone right outwards to the limit of the ring. There are no published figures of the 'double-ring' described by Strasburger in a larch to which reference has already been made, but Fig. I4, from a section taken at random from a species of Abies, shows that the thinner-walled cells between the first and second thick-walled zones are actually larger than those on either side of them. S. J. Record's illustration of Funiperus virginiana shows more clearly a similar state of things, which would appear to be the normal result of a renewal of cambial activity towards the end of the growing season. But in the abnormal rings of the defoliated larches, as Figs. 4 and I 3 show, the cells become ever smaller up to the end of the year's growth, even though they are without any characteristic autumn thickening. In the two Japanese Larches from Oxford the ring of I9I I was bounded by cells that appeared as if checked in development before they had properly outgrown the flattened prismatic form and thin-walled condition of the cambial cells from which they were derived. But almost to the last the cells of the abnormal rings in Figs. 4 and 13 are rounded though unthickened, showing that they had been growing since they were cut off from the cambium. Their relatively small size corresponds to that of the outermost cells of normally thickened autumn wood (which are not always markedly flattened), and it may be supposed that they are not thick-walled for the simple reason that there was not sufficient food-material at hand, although the cambial cells still retained their normal capacity for repeated division. The mere formation of new cells and the thickening of their membranes must be regarded as two distinct phenomena, governed independently of each other by stimuli at present insufficiently understood. ${ }^{1}$ A case like that of Fig. 3 seems to represent a genuine attempt at forming autumn wood, in which, however, the extra deposits of thickening upon the wall had to be omitted. Only in the extreme case shown in Fig. 9, between A and B, where the cells at the boundary are no smaller than those of the succeeding

1 The thickening and lignification of the elements often proceeds very slowly in young normal larches, so that in August there may be found a zone of thin-walled cells between the cambium and the completed tracheides, which last may still give the cellulose reaction in the thick secondary layers of their walls. 
spring zone, may it be supposed that growth had ceased for the year before the due time had come for the seasonal peculiarity of autumn wood formation with its attendant reduction in the size of the cells.

It has been remarked that the first year to show the effects of defoliation has no thick-walled autumn wood, at least at its ultimate boundary, but as a rule the cells here are of much smaller size than those formed in the spring or early summer (Figs. I and 3). We have, as it were, unthickened autumn wood, at the close of a fairly broad ring. Subsequent years, however, show much narrower rings, with or without a few rows of cells with more or less strongly thickened walls and flattened shape, and exhibiting that sharp demarcation from the spring wood that is general in the narrower rings of Coniferous timber (Figs. I, 2, 4, 7, and cp. Fig. I 3 from a part of a tree dating back to before the commencement of the attack). Possibly this recovery means that defoliations were less severe after the first two years of the attack; the only records available were found to be inaccurate with regard to individual trees, however they may apply to whole plantations. The exceptionally strong development of autumn wood in the outermost two rings of the whole of tree $\mathrm{D}$ and of the lower parts of trees $\mathrm{E}$ and $\mathrm{F}$ has already been referred to the thinning out of the Thirlmere plantations from which these three trees came, but even here it is not very clear why a tree can once more begin to produce well-thickened autumn wood before its rings have been able to reattain their former breadth. Probably the spring wood is formed out of the reserves stored up over winter, while the autumn wood is supplied from the assimilated products of the current year. Consequently the defoliation endured in any particular year would have a greater effect on the autumn wood,-indeed, the spring wood is largely formed before the defoliations begin in June. It may be pointed out also that, other things being equal, decreasing breadth of ring up to a certain point means an increasing proportion of well-formed autumn wood, so that slow grown trees often yield the harder timber. ${ }^{1}$ But that the hardness absolutely depends on the percentage of autumn wood would be an erroneous conclusion. ${ }^{2}$ Even in different parts of the same tree great variations of hardness are to be met with that cannot be referred to differences in the ratio of thick-walled to unthickened cells. As a rule it was remarked that in the larches investigated the hardest sections, judging from the wear of the razor used to cut them, were those where the autumn wood was very sharply demarcated. ${ }^{3}$

\section{(c) Resin Duct Formation.}

Finally, attention may be drawn to the presence of abnormal resincavities in some of the rings that are deficient in autumn wood. Fig. I 5

${ }^{1}$ Cp. Schwarz, p. $35^{\circ}$ and the foot-note on p. 348.

${ }^{3}$ Cp. Record, p. 40.

${ }^{2}$ Cp. Hartig (1), p. 4 o. 
shows the ordinary zones of traumatic ducts that are formed year after year in the neighbourhood of injuries, such as the cankers caused by Peziza Wilkommii, and Fig. 16 shows a similar zone more highly magnified. ${ }^{1}$ These ducts are very different from the irregular cavities shown in Fig. I7: which seem traceable in a more elementary stage of development in Fig. I8, from another part of the same tree. It may be pointed out that the phyllophagous larvae of the Sawfly can hardly cause any traumatic effect down in the trunk, and the ovipositor of the mature insect can only harm the tender shoots. Whether these abnormal resin-cavities are the result of an attempt to make normal ducts, in traumatic zones or otherwise, which has become abortive through declining growth-energy and lack of food, has not been decided.

In conclusion, I wish to express my warmest thanks to Professor Somerville for the very ready way in which he put the resources of his laboratory at my disposal, and for helpful suggestions. I am indebted also to Professor Vines for facilities that were of great assistance in expediting the work, and to Professor R. W. Phillips, University Coliege of North Wales, Bangor, for kindly criticism. The photographs were made from my own preparations and under my direction by Mr. Alfred Robinson of the University Museum.

\section{SUMMARY.}

I. The material investigated was for the most part furnished by trees that had been repeatedly defoliated by larvae of the Large Larch Sawfly.

2. Premature defoliation means a greater or lesser degree of starvation.

3. Starvation affects both the quantity of the growth-increment and the structure of the wood formed.

4. If starvation is severe, growth may quite cease over certain parts of the cambium-mantle while other regions of it are still active. Growth is especially reduced in the lower parts of the tree, where the rings are normally narrower than higher up. Consequent on this regional inactivity of the cambium some rings may run only part of the way round a section of the trunk, or may even be wholly lacking. In larches killed by the defoliations growth ceased entirely at the base a year or more before the death of the tree.

5. The effects of climatic variation have been negligible during the last few years, as far, at least, as some plantations are concerned.

6. The first visible effects of defoliation in the structure of the wood is the reduction of the proper thickening of the walls of the cells of part or all of the zone of autumn wood, without much decrease in the breadth of the whole ring. Subsequent years may show quite normal autumn wood before the rings have recovered their former breadth.

\footnotetext{
${ }^{1}$ Cp. Tschirch, p. II90; also Thomson, Figs. I and 2.
} 
7. The same ring may show remarkable differences in the autumn wood formation on opposite sides of the tree, and in such a way as must be referred to the positions of the different branches, pending further investigations.

8. The outermost cells of the autumn wood may have their walls unthickened, though those farther inside may be normal in this respect. The lack of thickening in the outermost cells might be referred to changes in the rate of the transpiration current during the development of the autumn wood. For defoliation would cause stagnation in the tracheides; whereas on the other hand the new growth of leaves that often follows after defoliation might make renewed demands on the water supply and stimulate the cambium to the production of thin-walled conducting cells.

9. Other examples give evidence rather that the outermost cells are unthickened merely because food ran short at the close of the year. The small size of the cells concerned supports this view, namely, that they are not a new formation of conducting tissue, but merely the 'mechanical' cells of typical 'autumn wood' starved in development.

IO. Abnormally formed resin ducts have been remarked in the defoliated larches; possibly they are causally connected with the starvation, as a pathological effect.

Magdalen College, Oxford, Dec., I9I 2.

\section{REFERENCES TO PREvious Publications.}

1. ANNAND : Quarterly Journal of Forestry. I9Io.

2. Haberlandt, G.: Physiologische Pflanzenanatomie. 1884.

3. Hartig, R. (1): Holz der deutschen Nadelwaldbäume. I885.

4. - (2): Holzuntersuchungen. I $90 \mathrm{I}$.

5. (3): Lehrbuch der Anatomie und Physiologie der Pflanzen. I89r.

6. HewitT : Journal of the Board of Agriculture. I 908.

7. Krabbe, G.: Sitzungen der Berliner Akademie. 1882.

8. Lutz, K. G. : Beiträge zur wiss. Botanik, herausgegeben von Fünfstück, i. I. 1895.

9. MacDougall : Journal of the Board of Agriculture. I906.

10. NöRdLINGER : Der Holzring. Stuttgart, I872.

11. Pfeffer, W. (1): Physiology of Plants, vol. ii, and Eng. ed. I903.

12. (2): Pflanzenphysiologie, Bd. i, Aufl. 2. I897.

13. Ramann, E., und BaUer : Jahrbuch für wiss. Botanik. I9II.

14. ReCord, S. J. : Economic Woods of the United States. I9I 2.

15. Sachs, J. (1): Lehrbuch der Botanik, Aufl. I. 1868.

16. (2): Vorlesungen über Pflanzenphysiologie. I 1882 .

17. Sanio : Pringsheim's Jahrbücher für wiss. Botanik. 1872.

18. Schwarz, F.: Dickenwachstum und Holzqualität von Pinus sylvestris. 1899.

19. Strasburger, E. : Leitungsbahnen. Histologische Beiträge, iii. I89I.

20. Thomson, W. P. : Botanical Gazette. April, I9I 2.

21. TsChirch, A.: Harz und Harzbehälter. 1906.

22. Wieler, A. : Jahrbuch für wiss. Botanik. I887. 


\title{
EXPLANATION OF FIGURES IN PLATES XLIX AND L.
}

\author{
Illustrating Mr. Harper's paper on Defoliation.
}

All are photomicrographs of transverse sections of the trunk of Larix europaea, with a magnification of $\mathbf{3 7}$ diameters except in the case of Figs. I and I 5 , which are magnified only I 3 diameters.

$x$ indicates the autumnal boundary of the first ring to be affected by defoliation. $y_{1} y_{2} y_{3}, \&$ c. denote the number of years that have passed since the formation of any particular ring. When comparison with other parts of the tree shows that certain rings are absent from a section (see p. 629) it is always assumed that these are the most recent rings of all (Figs. I6, I7, I8), unless there is positive evidence to the contrary (as in Figs. 6 and 7 ). $\mathrm{M}=$ multiple ring.

\section{PLATE XLIX.}

Fig. I. Tree D. Westmorland. Thriving. Showing the first effects of defoliation four rings from the outside. $16_{2}^{1}$ feet from ground. $\times$ I 3.

Fig. 2. As above. II feet from ground.

Fig. 3. As above. 33 feet from ground, showing the third ring from outside broader than in the foregoing lower section, Fig. 2.

Fig. 4. Tree B. Merioneth. Thriving. Showing first effects five rings from outside. Io feet from ground.

Fig. 5. Tree C. Merioneth. Thriving. Showing partial disappearance of second ring from outside. Base of tree.

Fig. 6. As above. 12 feet from ground.

Fig. 7. Tree B. Merioneth. Thriving. Cp. with Fig. 4. The third ring from the outside is only shown at A. Base of tree.

Fig. 8. Tree E. Westmorland. Dead. Two outermost rings have completely failed. I $6 \frac{1}{2}$ feet from ground.

\section{PLATE L.}

Fig. 9. Tree D. Base of tree. Cp. with Figs. I and 2 at I $6 \frac{1}{2}$ and II feet from ground respectively. Boundary of fourth ring scarcely visible, between $\mathrm{A}$ and $\mathrm{B}$.

Fig. 10. Tree F. Westmorland. Dying. $27 \frac{1}{2}$ feet from ground.

Fig. II. Tree C. $3^{2}$ feet from ground. Cp. with Fig. 12 and Figs. 5 and 6 , and with Table VIII.

Fig. 12. The opposite side of the same section to that shown in Fig. II.

Fig. I3. Showing the fusing up of 'multiple rings' in a larch-tree before the Sawfly attack commenced.

Fig. I 4. Section of Abies timber, showing a 'double ring'.

Fig. I5. Tree F. Section near a wound (canker), showing traumatic zones of resin ducts, especially in the spring wood. $\times \mathbf{I} 3$.

Fig. I6. Tree E. Cp. Fig. 8. Zone of resin ducts, probably traumatic. Base of tree.

Fig. I7. As above. II feet from ground. Ducts abnormally formed.

Fig. I 8. As above. I $6 \frac{1}{2}$ feet from ground. Cp. with Fig. I 7 the weakly formed cells between $\mathrm{A}$ and $\mathrm{B}$. 
Annals of Botany,
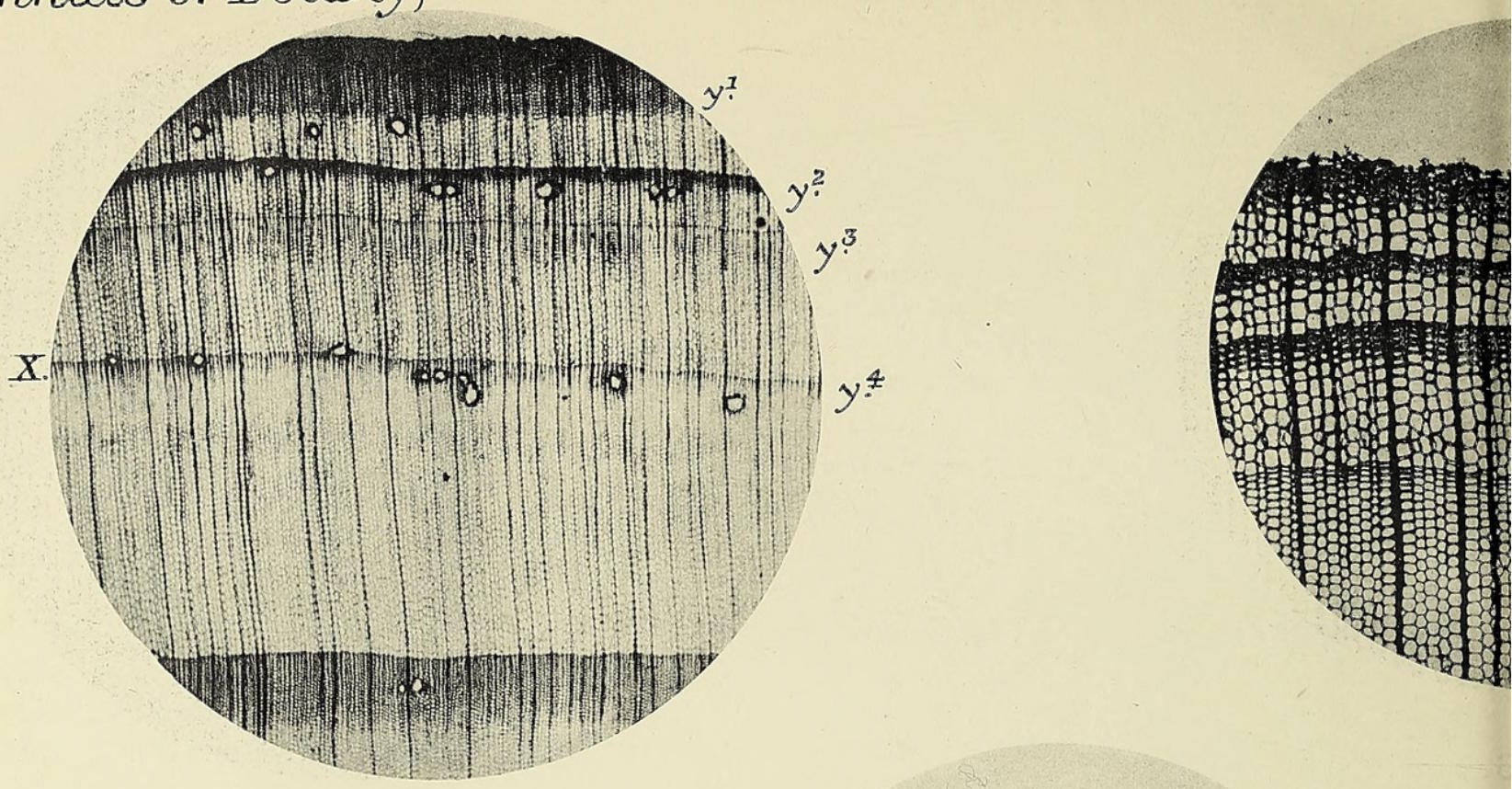

1.

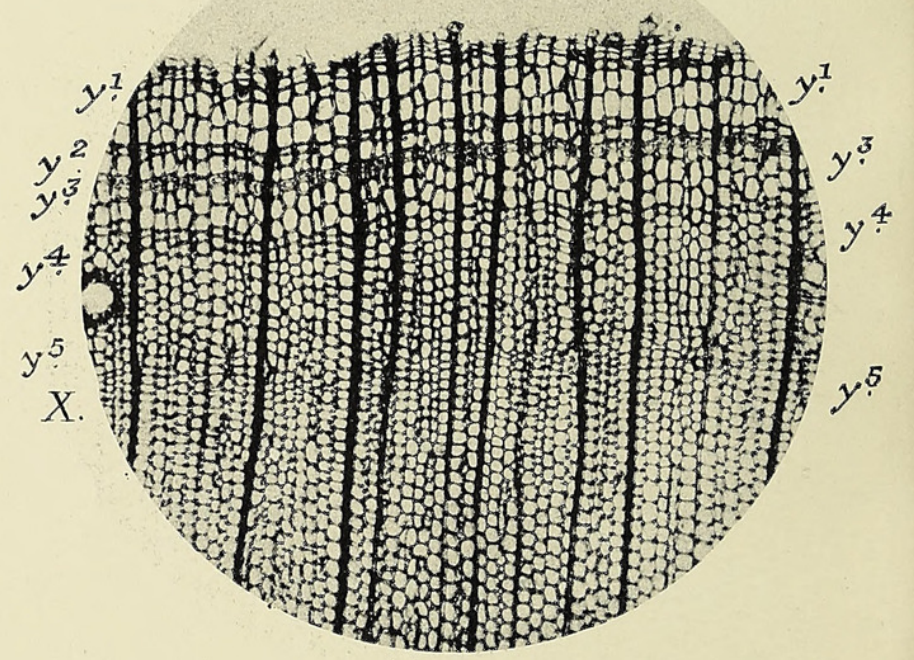

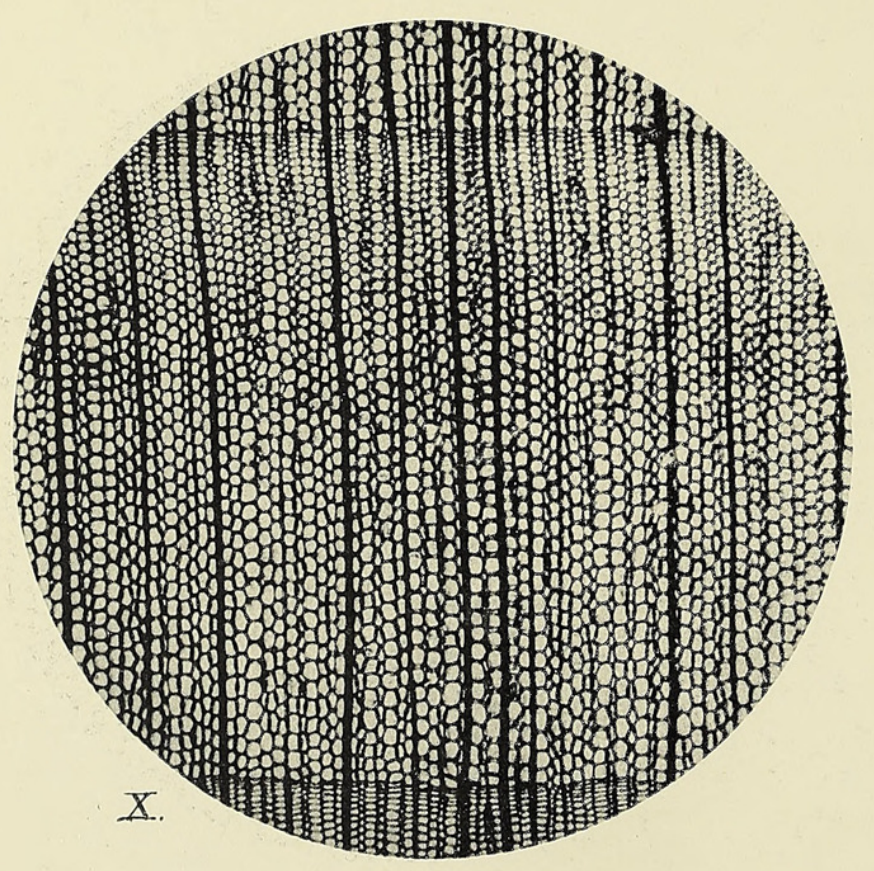

3.

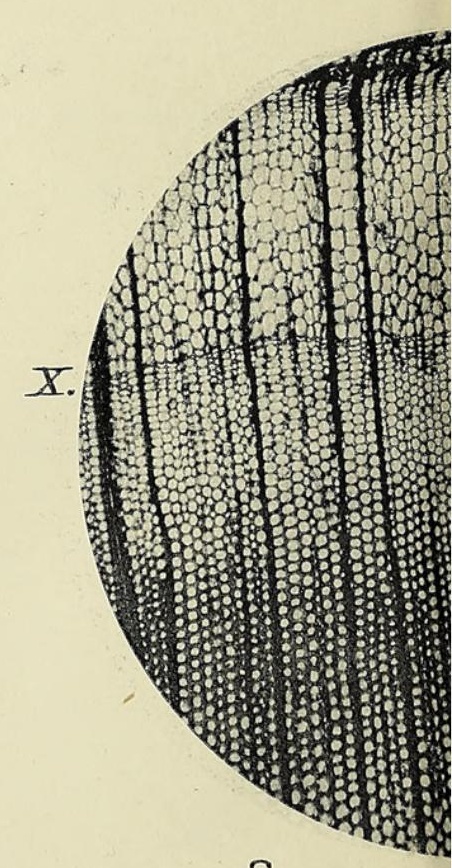

8. 


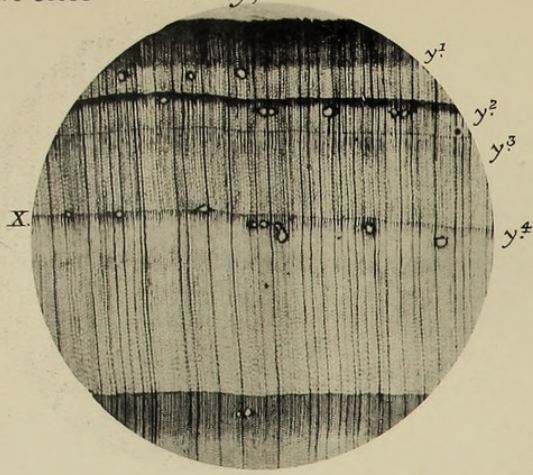

1.
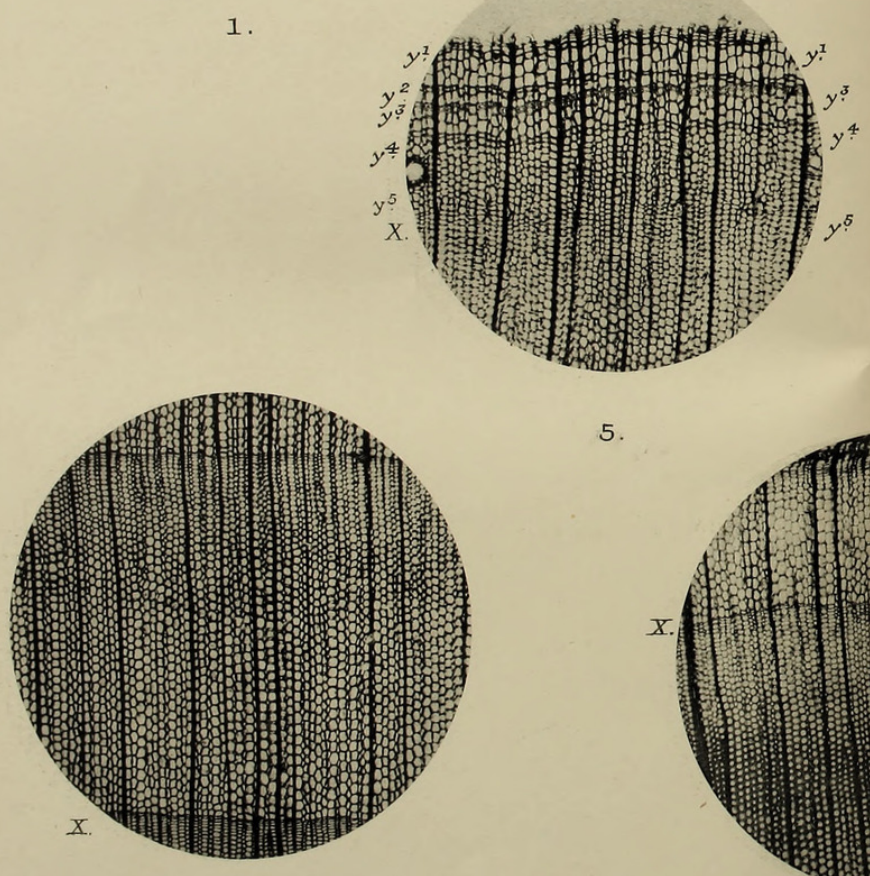

3.

HARPER - DEFOLIATION

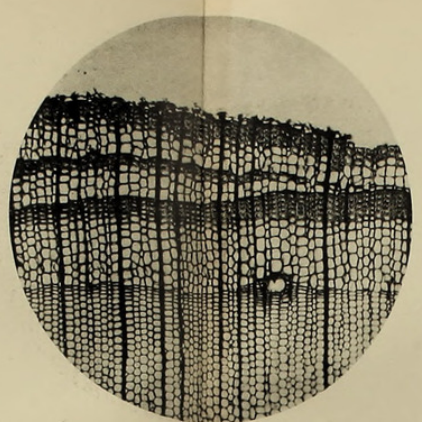

6.

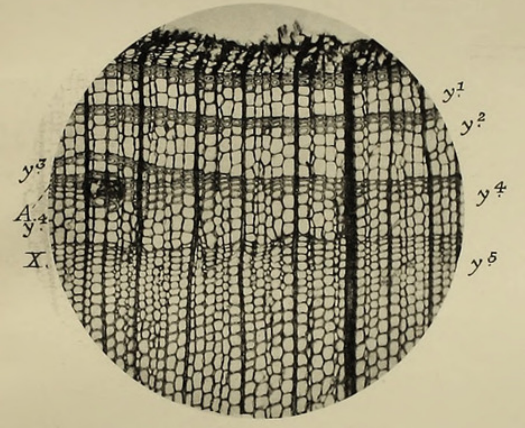

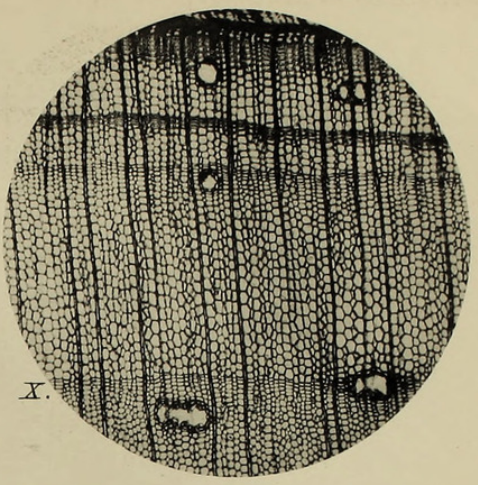

2.
5.

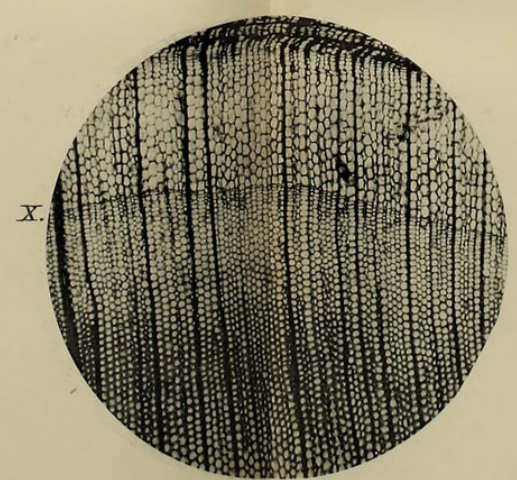

7.

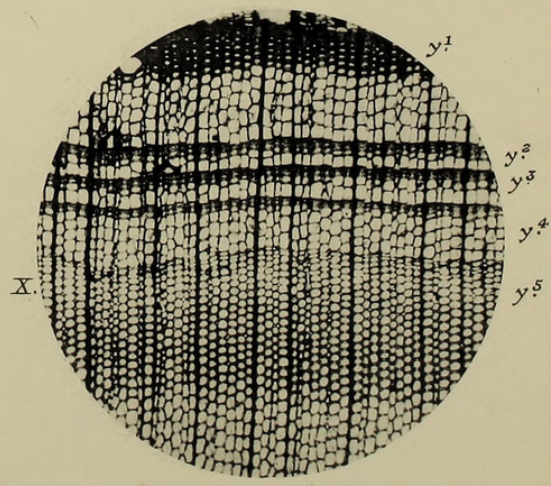

4.

Huth, coll. 
Annals of Botany,

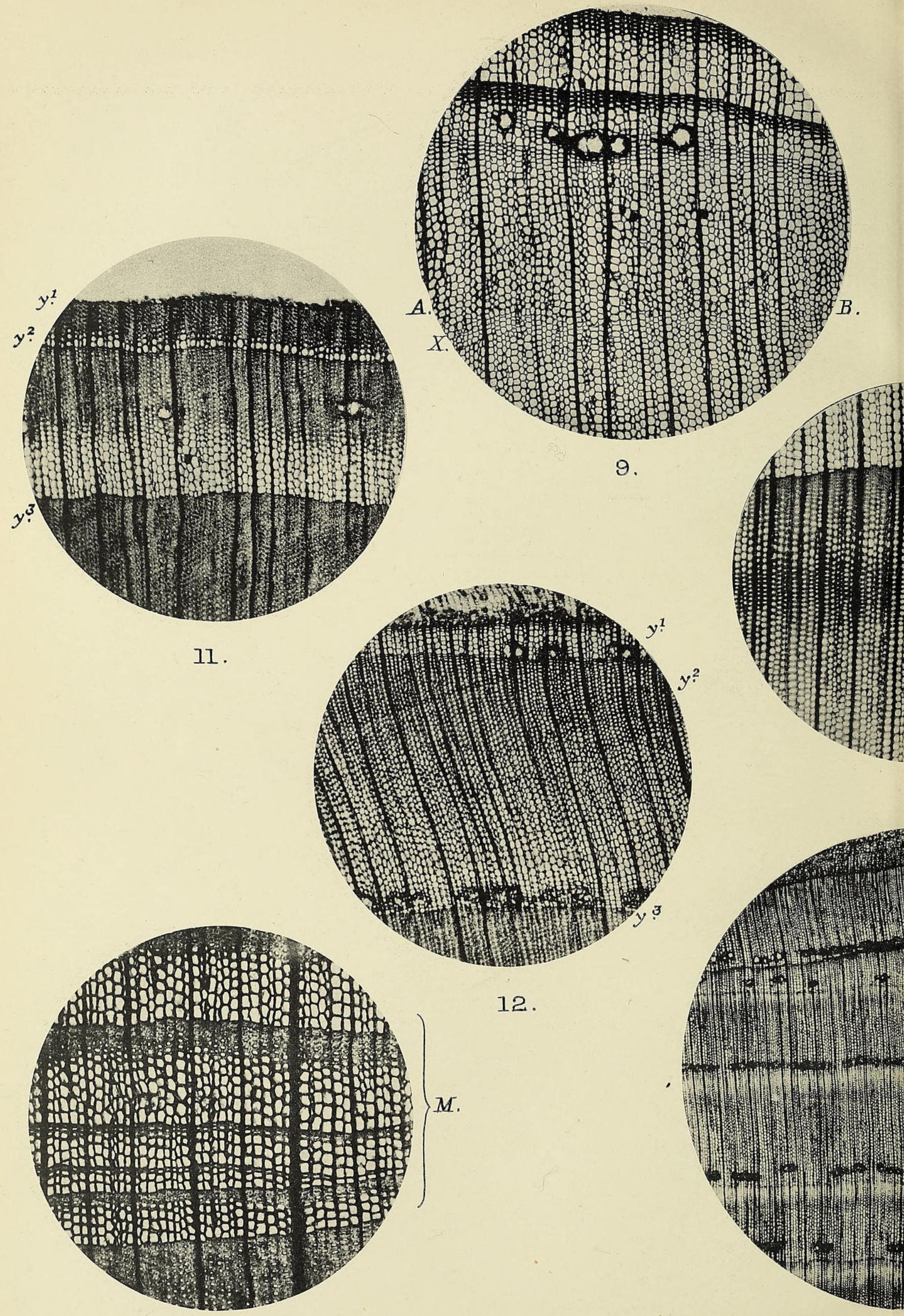

13.

HARPER - DEFOLIATION. 


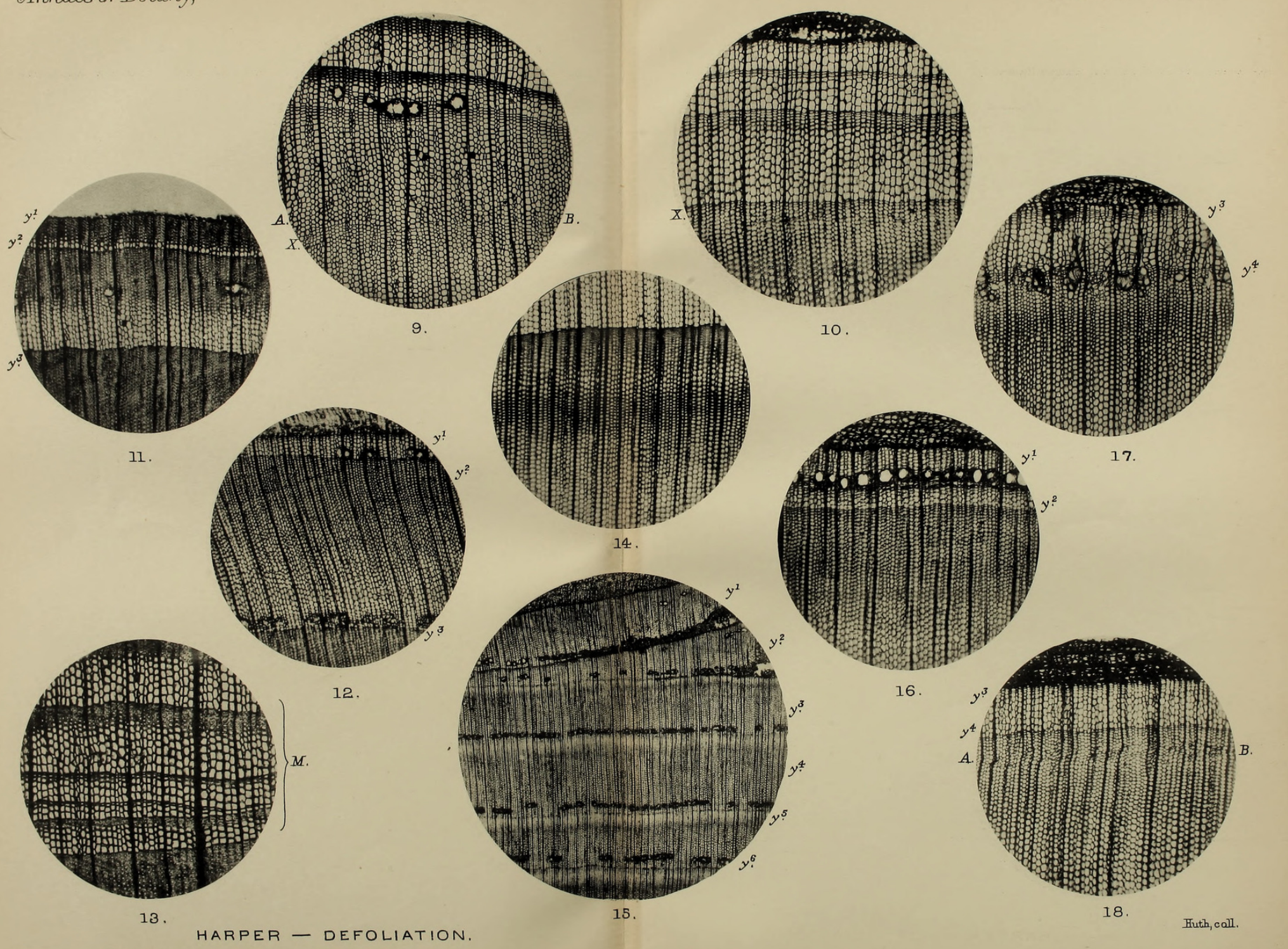




\section{$2 \mathrm{BHL}$ Biodiversity Heritage Library}

Harper, Alan G. 1913. "Defoliation: its effects upon the growth and structure of the wood of Larix." Annals of botany 27, 621-642. https://doi.org/10.1093/oxfordjournals.aob.a089480.

View This Item Online: https://www.biodiversitylibrary.org/item/237410

DOI: https://doi.org/10.1093/oxfordjournals.aob.a089480

Permalink: https://www.biodiversitylibrary.org/partpdf/319993

\section{Holding Institution}

Smithsonian Libraries

\section{Sponsored by}

Biodiversity Heritage Library

\section{Copyright \& Reuse}

Copyright Status: Not in copyright. The BHL knows of no copyright restrictions on this item.

This document was created from content at the Biodiversity Heritage Library, the world's largest open access digital library for biodiversity literature and archives. Visit BHL at https://www.biodiversitylibrary.org. 